\title{
ДИСЦИПЛІНАРНЕ РЕЛІГІЄЗНАВСТВО
}

Відділ філософії релігії Відділення релігієзнавства ІФ НАНУ протягом 2006-2008 років виконував означену планову тему. Нижче подаємо іiі розділи в тезовому викладі. Повністю матеріал дослідження буде видрукувано в монографії за такою ж назвою, яка вийде у світ до кінця 2009 року. Книгою можна буде користуватися як навчальним посібником на спеціалізаціях з релігієзнавства.

\section{План тезового видруку}

Вступ Предмет релігієзнавства як гуманітарної науки (д.філос.н. А.Колодний)

Розділ 1 Релігієзнавство в його дисциплінарних виявах (д.філос.н. А.Колодний)

Розділ 2 Релігієзнавство і теологія (д.філос.н. А.Колодний)

Розділ 3 Богословське релігієзнавство в його предметному змісті (д.філос.н. В.Шевченко)

Розділ 4 Філософія релігії: предмет галузі (к.філос.н. О.Горкуша)

Розділ 5 Феноменологія релігії в ії̈ суперечливому баченні (к.філос.н. О.Сарапін)

Розділ 6 Психологія релігії як дисциплінарне утворення (к.філос.н. Г.Кулагіна)

Розділ 7 Конституювання етикології релігії (к.філос.н. Н.Гаврілова)

Розділ 8 Соціологія релігії в архітектоніці релігієзнавства (к.філос.н. М.Бабій)

Розділ 9 Етнологія релігії як галузь релігієзнавства (д.філос.н. Л.Филипович)

Розділ 10 Політологія релігії: становлення і зміст (к.філос.н. О.Бучма)

Розділ 11 Правологія релігії в її предметі та структурі (к.філос.н. М.Бабій) 
Розділ 12 Культурологія релігії як сфера релігієзнавства (д.філос.н. В.Бодак)

Розділ 13 Історія та історіософія релігії: предметний зміст і відмінність (д.філос.н. Б.Лобовик)

Розділ 14 Географія релігій як галузь релігієзнавства (д.філос.н. Л.Филипович)

Розділ 15 Конфесіологія релігії як релігієзнавча дисципліна (д.філос.н. В.Климов)

Розділ 16 Герменевтичний аспект релігієзнавства (к.філос.н. Р.Трачук)

Розділ 17 Практичне релігієзнавство як нова дисциплінарна складова фаху (д.філос.н. А.Колодний)

Висновки Актуальні проблеми українського релігієзнавства (А.Колодний)

\section{ВСТУП}

\section{ПРЕДМЕТ РЕЛІГІЕЗНАВСТВА ЯК ГУМАНІТАРНОЇ НАУКИ}

Визначення проблем або ж завдань тієї чи іншої галузі знання то одне, а з'ясування іiі предмету - то інше. Окрім гносеологічних чинників у поглядах дослідників на предмет релігієзнавства значну роль відіграють соціальні фактори, інтелектуальний і культурний рівень розвитку суспільства. Втім визначальним у витлумаченні предмета релігієзнавства $є$ характер підходу до релігії та загальне розуміння природи, цінності та іiі функцій, що побутують в культурній свідомості тієї чи іншої епохи.

Особливістю релігії є те, що в ній відображаються не якісь зовнішні щодо людини природні чи суспільні сили, як донедавна твердилося, а такий стан, який

можна назвати самовизначенням у світі, пошуком і здобуттям людиною самої себе. Будь-яку релігійну систему характеризує віра в трансцендентне. 3 огляду на це, особливістю релігії $\epsilon$ й те, що вона виступає як засіб позалогічного освоєння людиною своєї причетності до процесів, що відбуваються у Всесвіті, зазнають впливу якихось вищих сил, які не піддаються логічному аналізу. 
Суть релігії полягає саме у відчутті людиною наявності в собі чогось надлюдського, що підносить ії над самою собою, утворюючи 3 неї щось нове, вселенське. Вона $є$ засобом самовизначення людини в світі, усвідомлення нею своєї богоподібності.

На відміну від філософії, яка задля розробки загальної теорії світу цікавиться не лише людиною, а й усім світом, їх співвідношенням, релігієзнавство зосереджується на першому елементі цього тандему, бо ж будь-яка релігійна система виступає не картиною світу, а картиною людини.

Включаючи в об'єкт свого дослідження співвідношення “людина - світ”, релігієзнавство насамперед акцентує увагу на співвідношенні “людина-індивід - світ”, вивчає своїми дисциплінарними утвореннями ставлення іiі до конкретних виявів цього «світу», при цьому не просто людини як фізичного тіла чи мислячої істоти, а людини як носія божественної суті в собі. Екзистенціалістська гіпертрофія проблем індивідуального існування $\epsilon$ саме тим, що характеризує релігієзнавче вирішення питань відношення “людина - світ”. При цьому людина не виноситься за світ, а тим паче не ототожнюється зі свідомістю, духовним, а відтак (що характерно для філософії діалектичного матеріалізму) не протиставляється буттю. Академічне релігієзнавство має розглядати людину саме в контексті буття, всередині його, у специфічному відношенні людини до нього як суб'єкта пізнання та дії, суб'єкта життя. При цьому релігія не ототожнюється лише 3 якимись ідеями, ритуалами чи інституціями, тобто формами iї зовнішнього вираження.

Окреслений вище підхід до дослідження релігійного феномена для українського релігієзнавства $\epsilon$ новим. Але дослідження ірраціонального вимагає включення в пізнавальний процес специфічних методів наукового пошуку, звернення до спеціальних понять і категорій, пізнавальних прийомів, якими оперує хіба що філософія ірраціонального, філософія інтуїтивізму. Це вимагає вироблення спеціальних понять-категорій, що $є$ і в богослів’ї, і в філософії ірраціоналізму та які не можна знайти у філософських системах, що грунтуються на раціональному пізнанні й позиціях матеріалізму.

Релігія $\epsilon$ не формою вираження безсилля людини перед пануючими над нею зовнішніми силами, що в ії свідомості набувають надприродного статусу, на чому наголошував Ф.Енгельс, а специфічним засобом іiі самоутвердження у світі, здобуття нею самої себе. То ж об'єктом відображення релігії $є$ не щось зовнішнє щодо людини, а саме процес людського самовизначення в світі через віру в 
свою причетність до світу надприродного, ірраціонального.

Релігія орієнтує не на втечу від життя, а на вироблення практичних рецептів, які дають можливість пом'якшити, компенсувати негативні наслідки ірраціональних впливів іннатурального щодо активно діючої людини. Релігія не $\epsilon$ відображенням якоїсь гостевості чи випадковості буття людини в світі, відходу іiі від нього, а навпаки - вона є доказом входження людини в світ, усвідомленням себе його невід'ємною часточкою. Саме тому вона не забирає, а стверджує в людині людське.

Нині ми є свідками переходу від онтологічної та космологічної аргументацій буття Бога до антропологічної, а відтак i до психологізації й етизації релігії. Буття Бога людина доводить своїм буттям. Осмислення людиною самої себе, тобто самоосягнення, виступає у ролі форми іiі релігійного досвіду. Цей процес ми б назвали не стільки суб'єктивізацією, скільки містифікацією релігії. Він відмінний від масової набожності, яка тривалий час домінувала й акцентувала увагу на суто зовнішньому, обрядовому боці релігії. Дійсний релігійний досвід полягає не в формальному дотриманні культових приписів, а, як зауважує Е.Фромм, у “відновленні людиною божественного образу своєї особистості”. Релігія в житті людини все більше починає відігравати роль символів життєдіяльності. Бог у свідомості віруючого постає скоріше як сила, що розчинилася у потоці самого життя, котра $є$ своєрідним орієнтиром, моральним еталоном життєдіяльності.

Природні й історичні об'єкти здобувають в релігії роль знаків: людських символів i ціннісних орієнтирів, а людина отримує можливість відчути свою причетність до процесів, які відбуваються у Всесвіті, але не мають конкретного логічного обгрунтування, виступають продуктом дії незбагненних Вищих Сил, що існують реально. Символи допомагають людині через інтуїтивне прозріння відчути реальну присутність у своєму особистому житті, житті всіх людей, у всьому Всесвіті побачити якогось Вищого Начала, Вищої Премудрості, Розумної Сили, що спрямовує й робить осмисленим як існування Всесвіту, так і їі власне існування.

Як і будь-яка сфера наукового знання, релігієзнавство має свій специфічний об'єкт дослідження. Кожна гуманітарна наука відтворює конкретну специфічну сторону буття людини в світі, певний вид іiі діяльності, життєвого досвіду. Як вище вже зазначалося, релігієзнавство має свій об'єкт дослідження, де у знятому вигляді фіксується певний аспект буття людини у світі, іiі ставлення до нього. Об'єктом релігієзнавства є відображення такого особистісного стану 
людини, який можна назвати станом самовизначення у світі, здобуття самої себе на основі віднайдення в собі того надлюдського, що єднає iii 3 трансцендентним. В своєму функціонуванні релігія виходить за межі свого індивідуального буття. Вона піддається доктринальній і обрядово-культовій (символічній) інтерпретації, входить у різні сфери людської життєдіяльності, сакралізуючи їх. Тому релігієзнавство у своєму предметі значно ширше, ніж у своєму об'єкті. Для означення останнього ми б вжили термін релігієлогія, підкресливши цим те, що про сутнісну природу релігії можемо мати лише слово, а не знання, що ними можна скористатися задля відтворення функціонального багатства релігійного феномена. Тож предметом релігієзнавства (в широкому його аспекті) $\epsilon$, крім природи релігії, іiі функціональність. Якщо об'єкт релігієзнавства є відносно сталим, то предмет його збільшується за обсягом і дещо змінюється в часі.

\section{РОЗДІЛ 1}

\section{РЕЛІГІЕЗНАВСТВО В ЙОГО ДИСЦИПЛІНАРНИХ ВИЯВАХ}

Різні світоглядні позиції, відмінні культурні традиції, навіть оцінки характеру наукової діяльності, призводять до появи безлічі дослідницьких установок релігієзнавців, їх теоретичних цілепокладань. Тому релігієзнавство можна поділити на академічне й богословське. На відміну від першого, останнє входить до богословського комплексу, розвивається на основі закономірностей цього виду духовності.

В західному релігієзнавстві поділ цей розглядається як вияв двох різних перспектив у ставленні до релігії - внутрішньої та зовнішньої. Він не пов'язується 3 філософськими чи світоглядними відмінностями в оцінках релігії. Якщо в XIX ст. релігієзнавці відмежовувались від теології, прагнули знайти відмінність своїх пошуків від богословських оцінок релігії, то зараз на Заході (та певною мірою вже і в нас) спостерігається все більше сходження академічного релігієзнавства на методологічні засади богословського, втрата ним рис світськості, сповзання на позиції певної релігійнофілософської концепції, а подеколи й на богословські установки певної конфесії.

Проте світськість, академічність релігієзнавства - не вияв ворожості до релігії, як це дехто прагне тлумачити їх. Особливістю академічного релігієзнавства $€$ дотримання світоглядного 
нейтралітету щодо релігії, певної толерантності, що відсутнє у богословському, конфесійно зорієнтованому релігієзнавстві.

Через відсутність чіткого визначення предмету релігієзнавства в ньому механічно поєднувалися різнопредметні знання про релігію. Втім релігієзнавство - єдина й водночас багатодисциплінна сфера гуманітарного знання. Підхід до нього як до якоїсь збірної науки, що поєднує в собі знання про релігію різних наукових галузей філософії, історії, археології, етнографії і тощо - поверховий, бо релігія завжди претендувала на статус загальної картини світу, тому вона, безумовно, залишила свій слід в усіх сферах суспільного й духовного життя, у з'ясуванні явищ природи. Саме тому в змісті кожної науки в той чи інший спосіб міститься певна інформація про релігію, котра проте не виступає основним об'єктом дослідження цих наук. Окрім того, в кожній конкретній науці релігія вивчається лише у відповідних аспектах, а не як цілісний духовний феномен, у всьому комплексі своєї функціональності й закономірностей розвитку.

Особливістю релігієзнавства та його окремих дисциплін $\epsilon$ те, що в них релігія виступає об'єктом дослідження; вивчається у поєднанні всіх структурних компонентів і всієї системи функціональності; різноманітність суспільних i духовних процесів розглядається у підпорядкованості саме розвитку релігії та її функціонуванню, а не як в інших науках, де релігія досліджується в контексті їх сфери пізнання світу; досліджуються закони певної предметної сфери буття людини в світі, що не поділяються на якісь частини, котрі не вивчаються іншими науками.

Релігієзнавство має свій, належний лише йому предмет дослідження, що виокремлює його в структурі гуманітарного знання. Ним є релігія в усій єдності іiі структури, функціональності й закономірності. Поява думки про релігієзнавство як своєрідний збірник релігієзнавчої інформації 3 різних конкретних наук пояснюється тим, що в своїх дослідженнях вчені ще чітко не вичленували той аспект буття людини в світі, котрий можна кваліфікувати як релігійний. Тут, з одного боку, тяжіє богословське бачення проблеми, коли характер буття зводиться до зв'язків людини 3 Богом, який виступає як щось зовнішне щодо неї (часто в антропоморфному аспекті); а 3 іншого - вводиться в обіг поняття існування людини як стражденної істоти, що в пошуках з'ясування причин такого свого стану робить висновок про існування якоїсь вищої детермінанти.

Проблема структури релігієзнавства й досі залишається не розробленою, хоча в наукових розвідках часто виділяються такі його 
дисципліни, як філософія релігії, психологія релігії, соціологія релігії, історія релігії, а останнім часом ще й феноменологія релігії, компаративне й герменевтичне релігієзнавство, деякі інші. Проте при виділенні окремих дисциплін релігієзнавства жодним чином не обгрунтовується основа цього структурування, не розглядається функціональний їх зв'язок між собою. Крім того, перераховані дисципліни ще певною мірою не концептуалізовані.

Якщо Д.Угринович поділяє релігієзнавство на два основних розділи - історичний і теоретичний, виділивши в останньому філософський, соціологічний і психологічний аспекти вивчення релігії (Угринович Д.М. Введение в религиоведение. - М., 1985. C.6-12), то Н.Мизов бачить у релігієзнавстві структуроутворюючі компоненти, що характеризують його переважно з боку філософської чи суспільно-наукової сутності. До останнього він відносить соціологічні, психологічні та історичні аспекти релігії. Крім того, Н.Мизов виділяє релігієлогію як особливу науку про релігійний феномен, підпорядковуючи ій вивчення відносно самостійної внутрішньої структури та логіки існування й розвитку релігії (Мизов Н. Религиознание: система и същност. - София, 1977. - С.31). Зауважимо, що філософії релігії дослідник залишає гносеологічні характеристики та розкриття містико-відображальної природи релігії.

Філософія релігії, хоч про неї багато писали, ще повною мірою не концептуалізувалася (Див.: Проблемы философии религии и религиоведения. Учебное пособие. - Калининград, 2003). У сучасному релігієзнавстві вона присутня в ролі філософії науки, а не філософії релігії. Як вважає Ф.Уейлінг, релігієзнавці ще не мають такої філософії релігії, що була $б$ універсальною за своїм використанням, відповідально ставилася до релігії й могла спрямувати інші дисциплінарні підходи до іiі вивчення, а не ізольовуватися чи прагнути панувати над ними.

Нинішня філософія релігії вивчає переважно якусь одну релігійну традицію (в основному християнську) і звертається при цьому до іiі ідеаційного компонента. Інші релігієзнавчі дисципліни в своїх пошуках є поліконфесійними, включають в контекст розгляду не лише християнство, а й інші релігійні течії, навіть первісноархаїчні вірування. Тож філософія релігії здобуде належну їй функціональність у структурі релігієзнавства лише за умови змістовного філософського синтезу дослідницьких здобутків окремих релігієзнавчих дисциплін, набуття нею ролі методологічної рефлексії в системі релігієзнавства, засобу аналізу мови релігії.

Вирішення питання структурованості релігієзнавства перебуває 
y прямому зв'язку із визначенням його предмета i зумовлене насамперед складною функціональністю релігії, відмінністю теоретичного цілепокладання різних релігієзнавчих дисциплін. Багатодисциплінарність релігієзнавства залежить також від світоглядних позицій і культурницьких традицій дослідників його структури.

Специфіку кожної дисциплінарної одиниці релігієзнавства, на нашу думку, можна визначити, з одного боку, через відмежування іiі від інших релігієзнавчих наук, з іншого - від теології. За основу виділення їх слід брати насамперед теоретичну зорієнтованість дослідницьких пошуків, а також параметри й сфери функціональності релігії. Так, філософія релігії, зайнята внутрішнім контекстом релігійного феномена, на неконфесійно зорієнтованому та позаісторичному рівні проводить концептуалізацію іiі природи i функцій в загальному аспекті; соціологія релігії, працюючи на конфесійному та позаконфесійному рівнях і займаючись зовнішнім контекстом релігії, розглядає іï функціонування i розвиток як специфічну підсистему на рівні суспільства (цілого чи окремих його сфер і структур, в тому числі і церковних об’єднань).

Психологія релігії вивчає психологічні особливості функціонування релігійності на індивідуальному рівні та 3'ясовує при цьому специфіку релігійних вірувань, уявлень, переживань особи, вплив релігії на іiі психологічний світ. Історія релігії відрізняється від названих вище дисциплінарних утворень релігієзнавства тим, що досліджує релігію не в статиці, а в динаміці. Конкретніше, не лише на рівні загальнотеоретичного відтворення іiі природи чи функціонування на індивідуальному чи суспільно-спільнісному рівнях, а й на рівні осягнення процесу становлення релігії як в іманентних ій історико-релігійних зв'язках, так i в загальному соціально-історичному й історико-культурному контексті. Тут ми не згодні з вченими, що зводять історію релігії лише до вивчення релігії 3 точки зору ii конкретно-хронологічного розвитку. Історія релігії, крім конфесійної конкретики, має ще й свою логіку, що виявляється в особливостях еволюції даного феномена від природних його форм до сучасних розвинутих систем світового масштабу. Логічне зняття історії релігії ми б назвали історіософією, котра покликана відтворити загальні закономірності історичного розвитку релігії, співвіднести в цьому процесі об'єктивне й суб'єктивне, стихійне й свідоме, традиційне й новаційне, етичне й релігійне. Саме в цьому аспекті, а не взагалі, як це твердить Ю.Кимелєв (Кимелев Ю.А. Современная западная философия религии. - М., 1989), історія релігії займається 
самою релігією. Особливістю історії релігії як релігієзнавчої дисципліни $є$ одночасне вивчення функціонування i зовнішніх i внутрішніх контекстів релігії.

Методологічні дискусії, які відбувалися в західному релігієзнавстві останнім часом, дозволили зробити висновки, що за своїми предметними й функціональними характеристиками близькими до філософії релігії $\epsilon$ феноменологічний та історичний підходи до неї. Серед релігієзнавців існує навіть думка, що саме поєднання цих двох підходів є основою єдиної сучасної науки про релігію.

Проте й досі феноменологія релігії як окрема галузь релігієзнавства ще чітко не концептуалізована, не є системним утворенням, що має змістовну й методологічну єдність. Утримуючись від екзистенційних, істиннісних й оціночних суджень, орієнтуючись на об'єктивність дослідницького пошуку, феноменологія релігії прагне осягнути окремі релігійні феномени поза їх зв'язками, послуговуючись так званим ейдетичним баченням, тобто методами вчування, інтуїції, конфесійно включеним дослідженням.

Наш час характеризується також появою герменевтичного релігієзнавства, що покликане розробити якусь придатну для вивчення релігії загальну теорію інтерпретації. Розвиваються корпоративне релігієзнавство, культурологія релігії, політологія релігії, правологія релігії, географія релігії, етнологія релігії і т.ін. Диференціація академічної гілки релігієзнавства - порівняно молодої галузі гуманітарного знання - триває.

Важливою для релігієзнавства $є$ також проблема дійсної сутності атеїзму. До їі вирішення слід підходити насамперед з позицій 3'ясування місця людини у світі, а не із заздалегідь визначеної антирелігійної зорієнтованості.

Атеїзм відтворює не процес заміни релігійного світорозуміння науковим, як це часто ще твердять, а насамперед утвердження буття людини, що не потребує постійних звертань до надприродних сил. Атеїзм - не $є$ антитеїзмом. Атеїзм - вільний від містифікації шлях людини до самої себе, до самопізнання, утвердження в собі цінності і дійсного смислу людського буття.

Однією з актуальних проблем для кожної релігійної системи $є$ проблема свободи волі людини. Питання стоїть так: вільна людина у своїх діях, чи кожний крок іiі діяльності абсолютно детермінований Всевишнім? Саме в цьому, а не у взаємному світоглядному протистоянні, на нашу думку, й пролягає різниця між релігією та атеїзмом. Релігія і атеїзм - не просто різні (тим більше 
взаємовиключаючі) духовні утворення, а протилежності єдиного цілого, єдність яких визначає його. Вони не взаємовиключаючі, а співіснуючі форми духовного осмислення та дії. Атеїзм покликаний не заперечувати релігію, а теоретично відтворювати механізм вільної діяльності людини. Тео й а-тео в житті людини завжди співіснують. Характер, рівень їх співіснування $є$ своєрідним мірилом свободи людини. Людина вільна у своїй діяльності. Атеїзм цікавить не діяльність людини сама по собі, а механізм вільної життєдіяльності, в процесі якої відбувається присвоєння i предметно-практична реалізація на основі пізнання закономірностей навколишнього світу, притаманної їй творчо-діяльнісної сутності (Див.: Колодний А.М.Атеїзм як форма світоглядного знання. - К., 1984. - С. 30-56). Відтак покликання атеїзму - розкрити джерело й механізм природноісторичного саморуху людини. Він $є$ не просто певною формою знання людиною власних якостей, взятих самих по собі та орієнтованих якимсь чином проти релігії, а специфічною формою самосвідомості, оцінки нею свого діяльного стану як реальної, визначеної творінням сутності. При такому розумінні атеїзм не виключається зі сфери духовного життя людства, не вносить в нього конфронтаційні відносини.

Виходячи 3 цього, вільнознавство (так попервах ми б назвали цю релігієзнавчу дисципліну, враховуючи можливу негативну реакцію громадської думки на термін атеїзмознавство) покликане, з одного боку, подолати примітивний підхід до функціональності релігії, що характеризує ортодоксальні форми релігійності, а з іншого - вивчити механізм вільної життєдіяльності на основі сповідування або несповідування духовного надсвітового Начала, Вищого Розуму, що $\epsilon$ джерелом буття всього сущого, в тому числі й людини.

Перед релігієзнавством сьогодні стоїть нелегке завдання: повернути атеїзму належне місце в системі духовних явищ, яке відповідає його справжній суті i не має антирелігійної зорієнтованості.

Сучасне академічне релігієзнавство характеризують такі риси як світоглядний плюралізм, позаконфесійність, відкритість, історизм, порівняльність, поліметодичність. Воно враховує різноманітні здобутки інших наук. Водночас воно є й творчим. Релігієзнавство долає методологічні обмеженості, що накладалися на пізнання релігійного феномена ленінізмом, зокрема, партійність, заідеологізованість, підхід до релігії як до акультурного й антинаукового явища. Водночас, сприймаючи наявні вже досягнення світового релігієзнавства, воно шукає й власні методи дослідження 
ірраціонального буття. При цьому враховується, що вивчення релігії потребує особливих методів, які докорінно різняться від тих, що застосовуються при дослідженні раціональних структур.

\section{РОЗДІЛ 2}

\section{РЕЛІГІЄЗНАВСТВО І ТЕОЛОГІЯ}

Актуальність дослідження співвідношення релігієзнавства i теології зумовлена не лише потребою розмежування їх предметних сфер, а й практичними проблемами. Так, за умов відокремлення школи від церкви, декларування законом світськості освітнього процесу дехто прагне підмінити релігієзнавчу освіту в школах і вузах богословською, передає викладання релігієзнавчих дисциплін в руки священнослужителів, проповідників деяких християнських конфесій. Проблемою $\epsilon$ також атестація наукових кадрів, які досліджують релігійні феномени. Потрібно мати чіткі критерії розмежування пошуківців 3 теології i пошуківців 3 релігієзнавства, зокрема богословського, ідентифікації вітчизняних і зарубіжних спеціалізацій наукових досліджень 3 проблем релігії, оскільки вживаний нами термін "релігієзнавство" інколи не знаходить еквіваленту у прийнятій в деяких країнах класифікації галузей наукових пошуків у сфері гуманітарного знання.

Насамперед зауважимо, що термін "теологія" не відображає того змісту, який вкладають в нього самі богослови. Оскільки сутність Бога непізнаванна, то, на відміну від інших наук, які предметом своїм мають дослідження реальних творінь Бога, теологія, згідно з вченням різних конфесій, своїм безпосереднім предметом має Боже одкровення, тобто слово Бога, виражене у Святому Письмі. Тому доречним було б замість терміну "теологія" (слово про Бога) вживати термін "теологлогія" (слово про слово Боже).

Історично термін "теологія" сягає часів Стародавньої Греції і $з$ самого початку не мав специфічного фідеїстичного змісту. Богословами тут називали тих, хто складав або повідомляв оповіді про богів, космос. Нерідко ними виступали жерці, обов'язком яких була розповідь у храмі змісту міфів. У Платона - це люди, які розробляють теологію в епосі чи трагедії. В ролі теологів виступали також "збирачі" і систематизатори міфів, а особливо генеалогій язичницьких богів (по типу "Теології" Гасіода). Зрозуміло, що така теологія не обов'язково повинна була мати характер віровчення. Ї̈ могла характеризувати навіть іррелігійність. 
Саме тому Ціцерон теологами називав вільнодумних послідовників грецького філософа IV ст. до н.е. Евгемера, який, прагнучи раціоналістично осмислити міфологію, розглядав богів як витвір людини.

Вперше термін "теологія" у близькому для подальшої його долі змісті використав Аристотель, позначивши ним вичленовану у своєму вченні "вищу споглядальну науку", якою $є$ спекулятивна "перша філософія", або ж метафізика. Теологія, на його думку, є вченням про першу причину, "певну сутність", вічну, нерухому і відокремлену від чуттєвих речей, що не має якоїсь величини, частин [Аристотель. Метафизика // Аристотель. Сочинения. В 4-х т. - Т. 1. - М., 1977. - С. 285.]. Але характерним $є$ те, що Бог Аристотеля, оскільки за своїми ознаками він був далеким від антропоморфних і політеїстичних богів рідної філософові Греції, ще не мав якихось зв'язків 3 релігією. Він виступав у ролі одного 3 філософських принципів у світобаченні Стагірита. Саме тому теологія Аристотеля входила як складова до його філософії. Більше того, католицька церква цей термін навіть не допускала у свій вжиток, вважаючи, що богословами можуть бути лише служителі культу інших релігій. Вона різко засудила свого теолога П.Абеляра (1079-1142) за те, що він запропонував слово "теологія" використовувати для означення філософського викладу доктрини християнської церкви [Абеляр П. Диалог между философом, иудеем и христианином // Абеляр П. История моих бедствий. М., 1959. - С. 95105.]. Але, зважаючи на всі ці застереження, процес переростання теології в інтелектуальну діяльність, зближення ії̈ з духовною традицією греко-римської культури поступово зростав. Усвідомлюючи ту прірву, яка існує між інтелектуальним рівнем античної філософії й примітивністю суджень християнського віровчення, широкий рух за філософську рефлексію про Бога розпочав саме Августин Блаженний, який за допомогою метафізики неоплатонізму прагнув гармонізувати віру й інтелект, "божественні істини" й набуті знання. Але питання відмежування філософії від теології (чи навпаки) ще не поставало. Більше того, оскільки всі прояви людської життєдіяльності розглядалися як еманація Божественної волі, а мислення - як наслідок Божого озаріння, то їх єдність розглядалась як вияв Божої благодаті.

Вперше усвідомив відмінність науки про одкровення, тобто непідвладне розуму осягнення Бога (теологія), і науки, що грунтується на розумі (філософія), Фома Аквінський (1226 -1274). Але філософія в нього є хоч і необхідною, але підпорядкованою наукою, оскільки вона опосередковано, через пізнання природного порядку буття веде до Бога, $\epsilon$ компонентом метафізичного обгрунтування Бога. Відтак філософія й 
теологія Фомою не примиряються, а співпідпорядковуються відповідно до міри їх досконалості. В кінцевому підсумку Аквінат у своїх розмірковуваннях підпорядкував філософію раціоналізму Аристотеля християнському ірраціоналізму.

Трансформація теології в самостійну сферу знання, дисциплінарна специфікація теології в історії європейської думки була надто повільною. Проте та рефлексія, яка розвивалася в межах теології, в кінцевому підсумку призвела до остаточного взаємного розмежування, а то й протиставлення у XVIII-XIX ст.ст. філософії і теології, чіткого визначення теології у своєму предметі. Саме в цей час християнська віра стала міцним фактором і традицією європейського соціальнодуховного життя, а церква набула розвинутих інституційних форм, відбулося відокремлення релігійної і світської освіти.

Етимологія слова "теологія" (гр. theos - Бог i logos - слово, вчення) засвідчує дихотомічність його змісту. На це звернув увагу ще відомий протестантський теолог Пауль Тілліх, поділяючи поняття "теологія" на два елементи: першим $\epsilon$ theos, бог, що дещо про себе повідомляє, стихія одкровення; другим елементом $\epsilon$ logos, розумне слово про те, що повідомляє Бог у своєму освідченні.

Полярність ідеї теології відзначав і С.Аверинцев, вичленовуючи в ній як надраціональне одкровення, так і раціоналістичний аналіз цього одкровення. Саме ж співвідношення позалогічного "Бога" і логічного "слова" про нього в структурі богослов'я, як це слушно зауважив дослідник, відтворює двох'ярусність іудео-еллініської культурної традиції Середземномор'я [Див.: Аверинцев С. Теология // Философская энциклопения. - М., 1970. - Т. 5. - С. 201.]. Якщо на нижньому ярусі містяться філософські розмірковування про Всевишнього як сутність, першопричину і мету існуючого (саме цей ярус Аристотель назвав у своєму вченні теологією), то на вищому - такі істини одкровення, які недоступні розуму і які Бог подає у своєму слові.

Прагнучи упорядкувати і класифікувати різноманіття людських знань і враховуючи цю полярність теології, французький богословсхоласт Гуго Сен-Вікторський (1096-1141) виділив в останній мирську, світську (theologia mundana) i божественну (theologia divina) теологіï. Якщо перша у нього $є$ найвищою серед умоглядних філософських дисциплін, то друга - одкровенням Бога, втіленим у логосі і таїнствах. Пізніше християнська теологія поділилася на природну (theologia naturalisi) i надприродну (theologia revelata). Об'єднує їх те, що предметом своєї рефлексії вони мають справу Бога, його слово, а не безпосередньо Бога. Якщо природна теологія пізнає Бога за його натуральним творінням, природним одкровенням, що 3 необхідністю 
передбачає включення в це осягнення розуму (через що, до речі, іiі не сприймають протестантські богослови), то надприродна теологія пізнає Бога шляхом осягнення змісту його одкровення, його "Святого слова". Власне останню теологію християнські ідеологи й розглядають як основу, серцевину всього теологічного вчення, адже "Бог, згідно 3 їх твердженнями, у своїй доброті i мудрості зійшов, щоб самому відкритися і відкрити таємницю своєї волі [Катехизис. - К., 1991. - С. 53.].

Все вище сказане про теологію, іï особливості і структуру дає можливість вибудувати таку схему:

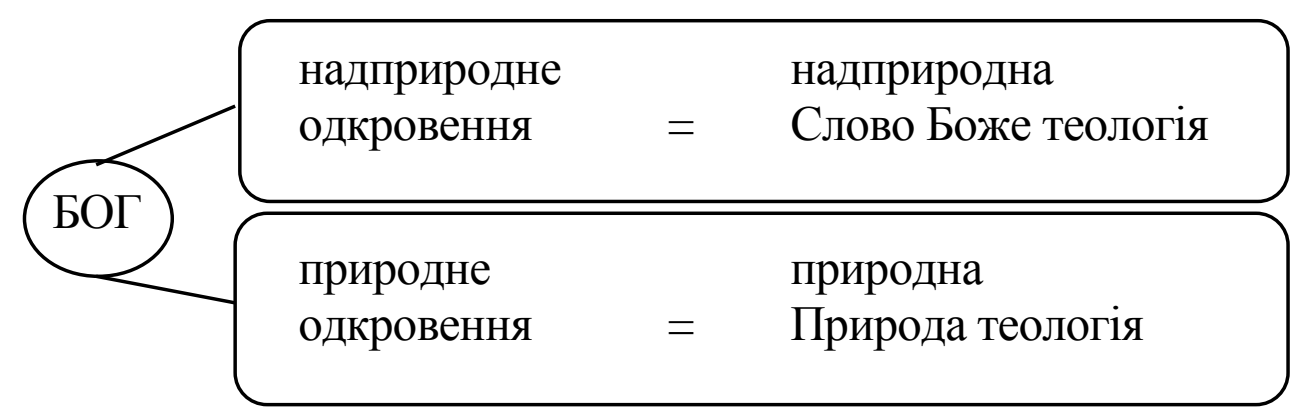

Яке ж місце релігієзнавства в цій схемі? Чи має воно при наявності двох видів теологій право на якийсь самостійний статус, а чи й взагалі на існування як окрема сфера пізнання? В чому його відмінності від теології, якщо воно все-таки конституюється як окрема cфеpa?

Насамперед зауважимо, що як і будь-яка інша галузь наукового пізнання, релігієзнавство, в якій би формі воно не виступало богословській чи світській (академічній), не визнає абсолютної усталеності якихось знань. Від теології воно відрізняється саме тим, що своє покликання вбачає в здобутті нового знання про релігію. Саме тому елемент віри в ньому присутній як принцип, а не як інструмент осягнення. Раціональному в ньому відводиться провідне місце. Всі положення релігієзнавства обов'язково повинні дістати емпіричне підтвердження, теоретичну доказовість. Цим воно відрізняється від богослов'я, яке свої положення не доводить до чуттєво-сприйнятної наочності чи логічної очевидності і чіткості.

Богослов'я замикається сферою Святого Письма. Образно кажучи, воно завмерло часово й просторово. Основним для нього $є$ Бог в контексті його функціонування. У богослов'ї, якщо й існують люди, суспільство взагалі, природне середовище, то лише як сфера діяльності Бога, як прояв його промислу, зафіксованого в оповідях Священних книг. Саме тому богослов'я вужче за предметом своєї зорієнтованості. Воно не виходить за межі слова про Бога i Божого Слова. 
Релігієзнавство, що засвідчує навіть етимологія самого слова, вивчає релігію як багатофункціональний феномен, а вже в контексті цього вивчення акцентує увагу і на Святому Письмі. Для вивчення релігії воно використовує як загальнонаукові, так і специфічні методи пізнання, що дає йому можливість проникати в сутність релігійних процесів, а не залишатися на поверхні явищ.

Проте співвідношення академічного й богословського релігієзнавства 3 теологією не однозначне. Академічне, або ж світське, релігієзнавство, крім вище названого, відрізняється від теології також його світоглядним плюралізмом i позаконфесійністю. Щодо богословського релігієзнавства, то тут співвідношення дещо складніше. Взагалі існує думка, що воно окремо не існує, що це $є$ та сама теологія. 3 такими висновками не можна погодитися з декількох причин: по-перше, якщо для теології релігія $є$ предметом опису, а то й інтенції, то для релігієзнавства, в тому числі й богословського, воно $є$ предметом дослідження, аналізу. Звернімося тут до відомої "Історії релігії" Олександра Меня. Вона, за словами самого автора, $\epsilon$ свого роду спробою релігійно-філософського й історичного синтезу. Дослідник інколи, щоб зрозуміти сутність тієї чи іншої релігії, так проникав у саму суть іiі віровчення, навіть певною мірою ототожнював себе 3 ii сповідниками, що його, здається, можна було навіть запідозрити в якійсь апології цієї конфесії. Далі, якщо релігієзнавство розглядає релігію в динаміці ії течій і форм, то теологія, будучи заангажованою на якійсь конкретній конфесії, розглядає релігійні явища в статиці, переносить події й процеси, які вона розглядає, у щорічну систему календарної святковості. Так, згідно 3 часово зміщеним, своєрідно спресованим богословським вченням, Iсус Христос щороку народжується, протягом року переживає всі події свого тридцятитрьохрічного життя і всі форми своєї земної діяльності, щороку воскресає і возноситься на небо. Тим часом у того самого Олександра Меня історія релігій постає як "потік рік і річечок, що несуть свої води в океан Нового Завіту". "Хоч у християнстві i завершився тривалий всесвітньо-історичний процес релігійних шукань людства, але "закваска Євангелій", - зауважує церковний історик, тільки почала свою перетворювальну дію" [Мень А. История религии. В 7-ми т. - Т. 1. - М., 1991. - С. 9-11.].

Різною $€$ також взаємна зорієнтованість богословського релігієзнавства i теології. Якщо остання використовує матеріал релігієзнавчих досліджень у своїх теоретичних побудовах, то перше, поклавши в основу своїх пошуків певну конфесійну догматичну систему, досліджує природу релігії, іiі історію, взаємозв'язки, 
взаємовпливи, функціональність. При цьому широко користується методами структурно-функціонального аналізу, абстрагування, порівняння, аналізу й синтезу, індукції й дедукції. Академічне ж релігієзнавство, хоч і вказує на певні відмінності різних релігій, водночас досліджує їх як однорідні явища, не віддаючи оціночну перевагу одній із них.

Претендуючи на роль якоїсь метанауки, метатеорії, теологія певною мірою знецінює релігієзнавчі пошуки, а їх неповноту, неоднозначність суджень, змінюваність оцінок навіть видає за підтвердження недосконалості релігієзнавчої інформативності. Більше того, претендуючи на абсолютну достовірність у вирішенні смисложиттєвих проблем і на світовідносну функцію в культурі, теологія в такий спосіб претендує на предмет і функції філософії, хоч, зауважимо, інтелектуальна респектабельність іï і значущість у системі культури залежить від того, як широко вона використовує для своїх потреб теоретичний і методологічний арсенал філософії.

Дуалізм природного і надприродного є основною характерною ознакою релігійної картини світу. Але на відміну від релігієзнавства, яке зорієнтоване на дослідження релігійного феномена як вияву визначення людиною свого місця в світі, теологія зорієнтована на надприродний світ, форми вияву ним своєї реальності й функціональності щодо світу взагалі й людини зокрема.

Теологія - це вчення про Бога, яке вибудоване в логічних формах на основі осмислення Священних книг, що розглядаються при цьому як одкровення, свідчення Бога про самого себе. Характерною особливістю теології, яка відрізняє іiї від богословського релігієзнавства, є: прийняття за істину концепції особистісного, абсолютного Бога; визнання того, що знання про Бога можна здобути лише з його "власного слова"; існування теології лише в межах теїзму. Цим пояснюється наявність теологій тільки в трьох чисто теїстичних релігіях - іудаїзмі, християнстві й ісламі.

Якщо теологія функціонує в межах свого власного категоріальнопонятійного апарату, то релігієзнавство (і це одна 3 його функцій) проводить відповідний аналіз природи, змісту, обсягу, форм цих понять i категорій. Адже без цього не можна зрозуміти структуру, функції і специфіку релігійної свідомості.

Релігієзнавство i теологія розрізняються також своїм функціональним призначенням, так би мовити метою своєї наявності. Теологія, незважаючи на свою схоластичність, усім своїм змістом орієнтована на утвердження релігії, пристосування іiі до змін суспільного буття. Релігієзнавство в обох формах свого теоретичного 
виразу покликане давати знання про релігію, залучати досягнення науки для пізнання релігійного феномена. Це в свою чергу спричиняє відмінність у способі підходу до догматів релігії з боку богословських релігієзнавців й ідеологів релігії. Якщо перші, не заперечуючи божественне одкровення, його змісту й авторитету, в свої дослідницькі конструкти включають логічні розмірковування i доведення, то ідеологи релігії при цьому посилаються на Святе Письмо, праці "отців" свого конфесійного віровчення, вбачають своє покликання не у відкритті якихось істин, а в доказовості тих істин, які виступають у формі догматів у певних релігійних концептуальних теоріях, мають довічний і незмінний зміст і вже явлені Богом у своєму одкровенні. Більше того, теологи кожної конфесії доводять достовірність догматичних установок саме своєї релігійної системи. У своїй діяльності вони підпорядковуються Церкві, яка орієнтує їх творчі пошуки, контролює відповідність їх букві Святого Письма. Такого не скажеш, звернувшись до аналізу дослідницької праці релігієзнавців. Вони опосередковано залежні від Церкви, а тому їм властивий широкий спектр суджень 3 тієї чи іншої проблеми, подекуди навіть специфічний. Тому, на відміну від теології, в релігієзнавстві, навіть богословському, може існувати велика кількість різних течій і шкіл. Якщо одні 3 релігієзнавців близькі до теології, то інші в дечому розходяться 3 нею, допускають вільне витлумачення деяких догматів і положень релігії. I чим більше у своїх розмірковуваннях релігієзнавець покладається на розум, тим більше у своїх логічних структурах він віддаляється від церковної ортодоксії, богослов'я, переходить на традиції світського дослідника. Так, лише в з'ясуванні проблеми витоків релігії такий дослідник спирається на міфологічну, анімістичну, соціологічну, психологічну, антропологічну, прамонотеїстичну та інші дослідницької концепції.

Різною також $\epsilon$ адресованість теології i релігієзнавства (відповідно: для віруючих - як буденного, так і теоретичного рівня релігійності; лише для освічених i мислячих людей віруючих i невіруючих), методи подачі їх (відповідно: через навіювання; через переконування). Богословські релігієзнавці можуть бути, а можуть і не бути духовними особами. В той же час дехто може поєднувати в своїй теоретичній діяльності функції релігієзнавця і теолога. Згадаємо тут Олександра Меня, Івана Огієнка, Степана Ярмуся, Івана Музичку, Івана Шевціва, Івана Ортинського, які є водночас авторами і богословських, i релігієзнавчих праць.

Релігієзнавство і богослов'я відрізняються також своєю структурою. Останнє включає догматичне, основне, моральне, 
пастирське богослов'я, екзегетику, патристику, літургіку та ін. Коло зацікавленості релігієзнавства інше й дещо ширше. Воно вивчає кожну з богословських дисциплін (чим не займається богослов'я щодо релігієзнавчих предметів), але не це визначає його структуру. Як уже зазначалося, структура релігієзнавства включає філософію релігії, історію релігії, психологію релігії, соціологію релігії, нові дисциплінарні релігієзнавчі утворення - феноменологію релігії, культурологію релігії, етнологію релігії, політологію релігії, географію релігії тощо.

Проте різниця між релігієзнавством, зокрема богословським, i теологією не $\epsilon$ абсолютною. Вона рухома, зазнає змін як у часі, так і в змісті. Але, визнавши відмінність богословського релігієзнавства i теології, необхідно бачити й те, що їх поєднує, а звідси - формує навіть думку про їх тотожність. Насамперед це визнання існування Бога, надприродного світу, і все це в певній конфесійній окресленості. Так, християнські богослови й дослідники аж ніяк не сприймають установки ісламу щодо Аллаха і його Пророка Мухамеда. Для них Бог існує в трьох іпостасях, які не зливаються і водночас не існують окремо. Як богословське релігієзнавство, так і теологія всі проблеми, які розглядають, - онтологічні, гносеологічні, антропологічні, моральноетичні та ін., розв'язують 3 позиції релігійного світорозуміння, орієнтуючись при цьому на зміцнення позицій релігії. На відміну від світського релігієзнавства богословська його гілка має рухому відмінність від теології. Так, англійський філософ Бертран Рассел, аналізуючи зміст філософії Фоми Аквінського, відзначав, що “перш ніж Аквінський починає філософствувати, він уже знає істину: вона повідомлена в католицькому віровченні... Але пошуки аргументів для висновку, що дається завчасно - це не філософія, а система упередженої аргументації” [Рассел Б. История западной философии. - М., 1959. - С. 481].

Конфесійна відмінність трьох головних течій християнства католицизму, православ'я і протестантизму - не знайшла істотного відображення в системі їх богослов'я. Серед богословських дисциплін всі вони мають догматичне богослов'я, моральне богослов'я (моральну теологію), біблійну теологію, пастирське богослов'я, фундаментальне богослов'я (основне богослов'я, християнська апологетика). В католицизмі $\epsilon$ ще й філософське богослов'я. Всі три християнські богословські системи онтологічно грунтуються на одкровенні, а антропологічно - на вірі.

Теологію, як і загалом суспільну думку сучасності, характеризує поєднання консервативних і ліберальних, реформаційних і радикальних 
течій. Розвиток християнського богослов'я як у минулому, так і нині, пронизують дві водночас взаємопроникаючі i взаємовиключаючі тенденції - обмежено раціоналістична й крайньо містична. Нині в теології спостерігається помітна зміна акцентів і орієнтацій. Теїстична думка нині виходить за межі витлумачень Бога і все частіше звертається до проблем місця людини у світі. Останнє сприяє все більшому проникненню в теологію нерелігійних форм теоретичної діяльності, розширенню поля іiї інтерпретаційної сфери.

Християнські богослови особливу увагу стали приділяти глобальним проблемам. В цьому знаходить відображення той факт, що в центрі уваги суспільної думки постає нині не окрема людина в іiі унікальності й самобутності, а людство як глобальне структурне утворення, що об'єднує однією долею всіх жителів планети.

Незважаючи на названі зміни в структурі i змісті своїх теоретичних побудов, теологія не відмовляється при цьому від своїх претензій відігравати головну світоглядну роль в культурі, бути домінуючим фактором у формуванні думки людини про світ і їі місце в ньому.

\section{РОЗДІЛ 3}

\section{БОГОСЛОВСЬКЕ РЕЛІГІСЗНАВСТВО В ЙОГО ПРЕДМЕТНОМУ ЗМІСТІ}

Покладаючи за мету стисло окреслити предметний зміст богословського релігієзавства, маємо, насамперед, усвідомлювати, що, незважаючи на термінологічну новизну означення самого феномену, богословське релігієзнавство правомірно ототожнювати 3 теологією як такою, а його появу в найширшому розумінні цього поняття співвідносити з часом, коли людина поставила перед собою проблему сенсу власного існування в його релігійному вимірі. Проте не далекі від істини й ті дослідники, які, дещо звужуючи семантичний спектр самого поняття, поширюють його лише на ті релігії, в яких Бог виступає першопринципом та основою існування і де богослів'я як чітко визначена система теологічних поглядів знайшла своє найбільш повне завершення. В такому сенсі термін «богословське релігієзнавство» як галузь дисциплінарного знання може 3 ексклюзивним правом застосовуватись щодо християнства. Принаймні на відміну від монотеїстичних іудаїзму, де теології взагалі не існує, або ісламу, теологічні принципи якого в переважній частині 
зведенні до постулування норм мусульманського права чи ж лише починають формуватися в певну богословську систему під дією секуляризаційних процесів сучасності (як то, зокрема, спостерігається в Туреччині), християнська теологія являє собою розроблену й теоретично завершену сукупність вчень, правил та норм життя кліру та його пастви, а також обгрунтувань щодо боговстановленості догматів і церкви як стовпа й підвалини істини.

Між тим, включаючи низку дисциплін, пов'язаних 3 богослужбовою практикою, християнське богослів'я не є однорідним i, попри кореневу спільність, дає підстави говорити про його виразну конфесійну специфіку в межах православ'я, католицизму та протестантизму. Хоча функціонально конфесійно відмінна християнська теологія мало чим відрізняється одна від одної i включає аксіологічну, догматичну, моральну та порівняльну специфікації, богословське забезпечення яких покликані здійснювати відповідно апологетичне (=основне), догматичне, моральне (=практичне) та порівняльне богослів'я. Складовою частиною цього функціонального комплексу християнської теології виступає також літургіка (теорія богослужіння), гомілетика (наука про теорію i практику проповідницької діяльності), канонічне право (=церковне право) та екзегетика (наука про зміст та способи тлумачення Святого Письма).

Крім того, виходячи із базових засад, християнське богослів'я прийнято поділяти на апофатичне (=негативне) та катафатичне (=позитивне) богослів'я, в основі яких лежать (нео-) платонівськоправославна та арістотелівсько-католицька парадигмальна специфіка. Зрештою, XX століття ознаменоване появою цілого шерегу нових теологій, серед яких на першорядну увагу заслуговують діалектична, екзистенціальна, секулярна, радикальна, феміністська, посттеїстична i навіть «чорна теологія», альтернативними інваріантами яких виступають також теологія визволення, теологія історії тощо.

Отже, з уваги на множинність християнських теологій, а також їх віронавчальні особливості та методологічні підходи в християнському богослів'ї доцільно використовувати й розрізняти два терміни, а саме «богословське релігієзнавство» як певну універсалію 3 iї христоцентричною заданістю та «конфесійне релігієзнавство» (=конфесійне богослів'я), що відображає типологію богословського мислення тієї чи іншої християнської конфесії.

В контексті змістового наповнення терміну «богословське релігієзнавство» не варто нехтувати і його другою складовою. Адже богословське релігієзнавство як своєрідна альтернатива академічного 
релігієзнавства є тим дисциплінарним утворенням, що грунтується на авторитеті Святого Письма, вірі в його богонатхненність та незаперечність божественого Одкровення 3 цілою сукупністю причинно детермінованих залежностей, які передбачають обов'язковість визнання ухвал Вселенських соборів, патристичних настанов, відповідних способів дослідження тощо. Зрозуміло, що підпорядковані завданню конфесійно-релігійного сприйняття, осмислення та оцінок тих чи інших проблем, богословські студії мають власне цілепокладання - розвиток, утвердження та апологію віровчення, що спрямовані на змилостивлення й звеличення Божества, уподібнення «образу й подоби» Божої своєму ідеалу, тому Абсолютному, 3 яким людина пов'язує найзаповітніші мрії і в служінні якому вибудовує лінію поведінки в горизонті земного життя та на вертикалі «Я - Бог». Воднораз, застерігаючи примат віри над розумом, богословське релігієзнавство, тяжіло й тяжітиме до розкриття основної загадки людського існування - його сенсу, що у вищих осягах зазвичай минається 3 імперативністю буттєвоонтологічних детермінант i знаходить своє пояснення та конечне виправдання в раціях вічного, сакрально-неминущого, провіденційного плану, в розгадці таїни Богом створеного світу. Кажучи конкретніше, в руслі християнських розумувань, речникові релігійних переконань випадає, насамперед, знати й поважати таїну Ісуса Христа, таїну Боговтіленого, Розіп’ятого й Воскреслого, таїну, яка виступає підставою віри, надії й любові, тими втіхою і щастям, в яких пізнається премудра сутність Ісусового благовістя, драма боговіддалення та почуття власної покликаності, в контамінації якої святоотцівська максима: «Для того Бог став людиною, щоб людина могла стати Богом» органічно перегукується й невіддільно поєднується 3 великим звіренням ап. Павла: «Я розіп'ятий Христом. I живу вже не я, а Христос проживає в мені» (Гал. 2:19-20).

У цьому зв'язку особливої значущості набувають містикотрансцендентні аспекти релігійного феномену, інтерпретаційний діапазон яких простягається від категоричного несприйняття до визнання єдиним і вищим засобом пізнання першосутності речей, того «ядра дійсності», осягнути яку можна лише надрозумовим чином i то тільки завдяки внутрішній здатності свідомості суб'єкта до індивідуального проникнення в метафізичну ірраціональну сутність світу [Шабанова Ю.А. За гранью рационального. Иррациональная метафизика Артура Шопенгауэра и пути становления духовной культуры XIX-XX веков. - Днепропетровск, 2002. - С. 37]. 
Втім розширення предметної сфери богословського релігієзнавства в контексті тих актуалізацій, до яких академічне релігієзнавство $є$ байдужим з огляду на принципову неможливість їх дослідної верифікації, є не тільки очевидною преференцією першого, але і його додатковим обов'язком, тією вимогою, яка не допускає самозаспокоєння, спочивання на лаврах фідеїзму, а ще браку тієї претензійності, в якій релігійно об'явлене та всіх зобов'язуюче унеобхіднює його справдження в земному житті, те христонаслідування, яким унаочнювався б подвиг співрозіп'ятих та співпогребенних в ідеальних візіях всезагального Добра, Краси й Любові.

Крім того, коли мовиться про відродження богословського релігієзнавства в його бажаній чи ж можливій повноті, то, розглядаючи будь-яке 3 питань під оптикою ідеального відзискання чи ж діагностуючи явища, процеси та тенденції 3 самокритичної середини, ми запобігли б двом важкоуникним крайнощам, а саме:

1.утрималися б від спокуси порівняльного релігієзнавства, яке досить часто призводить до порівняльної релігійності, що іноді гіпертрофує ядро духовності або стратифікує іï аксіологічні домінанти;

2.уникли б конфесійної чванливості, зведення значної гами питань церковно-релігійного спектру до підкреслення історичних заслуг чи ж наголошення власної деномінаційної винятковості, за яких нерідко не тільки втрачається «аромат» істиності, але й редукуються до нуля вихідні релігійні засади.

Під оглядом вищезазначеного предметне поле досліджень богословського релігієзнавства може стати плідним i взаємодоповнювальним дискурсом його академічного аналогу, тим увиразненням, яке поєднується з Божим одкровенням i в своїй життєвій співвимірності сприятиме кращому вирозумленню на проблематиці міжконфесійних взаємин, а головне детермінуватиме пробудження центрів чуйності, того прихованного смислу речей, в якому відчитуються недовідомість Істинного - повсюдне відчуття Божої всеприсутності та пізнання вищого призначення людини як Його виняткового творіння. 


\section{РОЗДІЛ 4}

\section{ФІЛОСОФІЯ РЕЛІГЇ: ПРЕДМЕТ ГАЛУЗІ}

Хоч найновіші вітчизняні підручники 3 філософії й визначають філософію релігії як “сукупність актуальних і потенційних філософських установок щодо релігії і Бога, філософське осмислення їхньої природи, сутності та сенсу", спробуємо більш чітко визначитися із предметним полем даної гуманітарної галузі. Про те, що визначення останнього є актуальною дослідницькою проблемою свідчить полеміка у філософських й релігієзнавчих колах 3 цього питання. Такий стан речей пов'язаний, зокрема, із становленням філософії релігії як, 3 одного боку, сукупності філософських роздумів щодо специфічних проблем, пов'язаних із абсолютними та трансцендентними вимірами людського буття, а з іншого - філософського осягнення самої релігії. У другому випадку “філософія релігії постає як розділ академічного релігієзнавства, в якому дається раціональне осмислення природи, сутності й сенсу релігійного феномену" [Колодний А. Релігієзнавство. Методичний посібник.- К., 2007. - С. 5]. Зрештою, усвідомлення філософії релігії галуззю академічного релігієзнавства стає можливим лише після інституалізації останнього.

Відтак дотепер ми спостерігаємо активну полеміку в наукових колах щодо визначення предметного поля філософії релігії. Ключовою для сучасних вітчизняних дослідників-релігієзнавців $є$ позиція, що філософія релігії є галуззю академічного релігієзнавства. Тому, якщо ми говоримо про філософію релігії як про галузь академічного релігієзнавства, а не як про філософствування на релігійну тематику (релігійна філософія або філософське розмірковування щодо божественного й абсолютного), то слід визнати, що i принципи академічного релігієзнавства тут є визначальними, а предметне поле філософії релігії не повинне виходити за межі предметного поля академічного релігієзнавства.

Академічне релігієзнавство є зовнішнім стосовно будь-якої релігійної традиції і грунтується на принципах об'єктивності, науковості, світоглядної незаангажованості, плюральності, актуальності, дуальності, історизму та діалектичності. Ось ця його зовнішність стосовно будь-якої релігійної чи ідеологічної традиції й зумовлює специфічність філософії релігії саме як галузі академічного релігієзнавства: дослідник виступає тут швидше у ролі спостерігача, що аналізує констатовані іншими параметри абсолютних істин, їхнє відображення у людській свідомості та функціональні вияви таких 
визначеностей в житті репрезентантів. I якщо власне філософські (чи вільнодумчі) розмірковування на релігійну тематику не спираються на якісь чітко встановлені загально-традиційні аксіоматичні твердження, а релігійно-філософські розмірковування спираються на чітку (конфесійну) аксіоматику, то до предметного поля філософії релігії як галузі академічного релігієзнавства, очевидно, й потрапляє саме така релігійно-конфесійна аксіоматика чи результати досліджень надприродної сфери філософами. Тобто, філософ релігії не досліджує божественне й не інтерпретує власного релігійного досвіду, але зосереджує свою увагу на розумінні вже представлених в інтелектуально-релігійному надбанні людства результатах дослідження божественного. Він, зрештою, змушений почуватися своєрідним “перекладачем" знання про божественне й його усвідомлення людиною універсально-раціональною мовою філософії.

Метою такої раціонально-мислительної діяльності є не осягнення Бога чи взаємодії Бога та світу, а швидше розуміння того, як певне уявлення про Бога впливає на людину та світ. Тому предметом дослідження філософії релігії у іiі вітчизняному сучасному розумінні не може бути абсолютне та божественне як таке, а лише його змістовне відображення в інтелектуальних продуктах віруючих, мислителів та філософів.

Зважаючи на складність та різноаспектність зазначеної проблематики у філософії релігії вочевидь найефективніше виділяти наступні ії підрозділи.

Насамперед метафізику релігії, сукупність проблем якої конкретизується тими релігійними ідеями, смислами та поняттями, які лежать в основі релігії, визначають іiї сутність та природу. Ця підгалузь філософії релігії фактично формує предметне поле релігієзнавства, визначає для нього головні поняття та категорії. Перш за все метафізика релігії осмислює об'єкт релігієзнавства - релігію через знаходження іiі сутнісних ознак, витоків та природи. Оскільки сутнісною ознакою релігії з позиції сучасного академічного релігієзнавства $є$ наявність віри в надприродне, то однією з найактуальніших проблем метафізики релігії $\epsilon$ визначення надприродного як такого, що лежить в основі природного, $€$ його джерелом і в релігіях фіксується поняттям “істинної реальності", "Бога", який є творцем світу, автором дійсності. Очевидно, що відразу постає необхідність визначення цілого ряду взаємозалежних понять. В такий спосіб поступово формується категоріальний інструментарій, за допомогою якого стає доступним для осягнення будь-який релігійний феномен. Одночасно метафізика релігії розглядає структуру релігійного комплексу, визначає його складові, взаємовідношення між різними 
елементами релігії як духовно-культурно-соціально-історичного феномену. Особливу увагу метафізика релігії приділяє концептуальній основі релігійних поглядів та уявлень, формам адекватного вияву останніх на рівні практичної релігійності, формуванню релігійної ідеології та іiі впливові на світогляд і життя iї прихильників. Користуючись здобутками інших розділів релігієзнавчої думки, метафізика релігії, в свою чергу, відіграє щодо них роль теоретикометодологічної основи досліджень та змістовного синтезу їхніх результатів.

Епістемологія релігії звертає увагу на те, яким чином релігії здобувають, оформлюють і верифікують те знання про Бога, людину, світ, що пропонується віруючим. Шлях віри, інтелектуальної інтуїції чи раціонального дискурсивно-логічного мислення доповнюються один одним у різних релігіях. Однак головним джерелом здобуття істинного знання релігією вважається містичний досвід, що є безпосереднім актом отримання знання від Абсолюту. Але таке знання, яке дається пророку, здобувається просвітленим, висловлюється Сином Божим значно перевищує пізнавальні можливості людини, а тому потребує специфічної адаптації в певному культурно-історичному контексті, витлумачення авторитетними релігійними діячами, верифікації на істинність в межах певної релігійної системи уявлень про світ, людину, Бога. Отже, процес формування знань у релігії $\epsilon$ досить складним i тривалим. В межах кожної релігії розробляються методології отримання та перевірки істинності знань про Бога, світ, людину, долю світу чи людини, проголошуються власні критерії до його істинності. 3 іншого боку, релігія як символічна картина світу та людини впливає на способи i напрямки здобуття людиною нерелігійної інформації про світ, активізує чи послаблює пізнавальні зусилля людини, спрямовані не на надприродний трансцендентний рівень, а на світ, що оточує нас. Зрештою, дійсність (з релігійної точки зору) постає відображенням істинного буття, а, з іншого - релігійне відображення дійсності впливає на іiі розуміння і сприйняття.

Попередньо оглянуті нами галузі філософії релігії замикаються на теоретичному рівні релігії. Натомість праксеологія релігії осмислює вияви, наслідки теоретичного змісту релігійного вчення на життєдіяльність віруючих. Визначення способів функціонування релігії в соціально-історичному плані дає можливість краще осмислити і різні форми релігії, їхню ефективність та роль у становленні й еволюції людини, людства у його індивідуалізованих (етнос, народ, нація) та загальних вимірах. Таким чином, праксеологія займається 
функціональним виявом релігії на індивідуальному, мікросоціальному, мезосоціальному та макросоціальному рівнях.

\section{РОЗДІЛ 5}

\section{ФЕНОМЕНОЛОГІЯ РЕЛІГІЇ В ЇЇ СУПЕРЕЧЛИВОМУ БАЧЕННІ}

Актуальність філософського (зокрема, феноменологічного) аналізу особистісних аспектів релігійного феномена зумовлена контекстуально явищами культурно-історичного порядку. За умов так званої антропологічної катастрофи зустріч 3 самим собою і $\epsilon$ цінною проблемою, коли феномен особистості висувається на авансцену історії.

“Антропологічне крещендо" сучасної духовно-культурної ситуації зумовило появу “нового стилю" (суб'єктивного) феноменологічних досліджень у релігійній сфері. Цей стиль пов'язаний 3 інтенціями конкретної людини. "Класична" феноменологія інтерпретувала смисл у термінах структур чи зв'язків між релігійними феноменами. Завдання полягало у виявленні більш глибоких зв'язків, які описувались би як типи, ідеальні типи тощо.

Щодо феноменологічних досліджень релігії “нового стилю”, то вони інтерпретують “смисл” швидше в термінах зв'язків, що існують між конкретними людьми i даними, які мають для них релігійне значення. Феноменолога цікавлять шляхи, якими людина сприймає в досвіді реальність, релігійну і світську, і який виражав цей досвід в словах і діях. Він запитує, які значення і за яких обставин відіграють роль для людини. Феноменолог розглядає свій матеріал і в світлі питань іншого роду : при вивчення релігії як виразу, що належить людині, його цікавить, що саме було виражене. Це і $є$ проблема смислу, зокрема "релігійного смислу".

В основі конкретної релігії як системи означень лежать певні специфічні проблеми, для яких вона прагне знайти вирішення, нехай навіть і не на рівні емпіричної реальності. Релігійний смисл можна інтерпретувати як вирішення специфічної проблеми чи групи проблем людського буття через “інтенціональне” усвідомлення вищого смислу життя і реальності. Тож релігії властивий антропологічний вимір. Це означає, що для розуміння того, що несе релігійний смисл людині чи спільноті, феноменолог повинен реконструювати проблему, для якої цей смисл забезпечує вирішення. Питання про адекватність такого вирішення залишається поза компетенцією дослідника.

Якщо людині завжди доводиться докладати зусиль для розуміння 
того, що говорять і роблять інші, то при вивченні релігії досліднику доводиться вникати в те, як інші ставлять основоположні питання буття і роблять спробу знайти їх вирішення в релігійній формі. Об'єктом його уваги повинна бути особистість, перед якою щось постає як абсолютне, а не саме абсолютне.

Феноменологічне дослідження має на меті розуміння смислу релігійного виразу для людини, котрій належить останній. "Серцевиною" цього смислу є інтенція, що його й породила. Вона може бути зрозумілою тільки опосередковано, по елементах їі виразу, шляхом інтерпретації. При цьому інтерпретаційна робота дослідника означає побудову ментального універсуму, орієнтованого на постановку фундаментальних проблем досліджуваної культури чи особи, та вказує напрям, де слід шукати вирішення цих проблем. Таким чином, дослідник намагається відтворити екзистенціальні проблеми i трансцендентні орієнтири чи виходи, що стоять за специфічним виразом, який він досліджує.

Факт релігійної значущості чогось для людини означає, що існує співвіднесеність 3 деяким інтенціальним об'єктом як 3 чимось третім, існуючим окрім людини i релігійного виразу. Визначальна риса релігійного значення полягає в тому, що інтенціальний “об'єкт” для певної людини має абсолютну достовірність і функціонує в системі іiі переконань, цінностей і дій як первинна цінність.

Кілька слів про методологічні принципи феноменології релігії. Феноменологія релігії, незважаючи на відсутність прямого впливу Е.Гуссерля, фактично використовує принципи гуссерлівської філософії, зокрема епохе (яке розуміється переважно як відмова від упередженості, в дещо меншій мірі, ніж у Е.Гуссерля, утримання від суджень про “природну” реальність і природу суб'єкта мислення) і ейдетичне бачення, чи відшукання та інтуїтивне осягнення структур і сутностей “чистої свідомості". Ці риси, а також орієнтація на інваріантні якості релігійної культури означають строгу відмінність феноменології релігії від історії релігій та психології релігії.

Р.Паммер, канадський методолог релігієзнавства, загальнонаукову цінність феноменологічного дослідження релігії вбачає в тому, що "вона показує спеціалістам на конкретній культурі, що будь-який релігійний феномен трансцендує галузь їх спеціалізації і $\epsilon$ тільки конкретним проявом чогось більш обширного і загального. Це, в свою чергу, породжує питання: чому дана релігія набирає вигляду одного i того самого “фундаментального феномена"? Феноменологія не може відповісти на це питання - для цього потрібен спеціаліст-історик”.

Дж.Томас вважає, що феноменологія релігії тим відрізняється від 
теології, що не може говорити про Бога, бо він не є безпосереднім феноменом свідомості.. Однак, відношення феноменології і теології не $\epsilon$ відношенням методу й системи. Феноменологія швидше передує вченню про Бога (теологіі) та вченню про релігію (філософії релігії), визначаючи й обгрунтовуючи їх вихідні положення і тим самим ніби стаючи початковим компонентом позитивної концепції.

Спробуємо простежити особливості релігійного об'єкта при феноменологічному аналізі. Феноменологія за допомогою принципу інтенціальності дозволяє обгрунтувати, навіть певною мірою описати наявність і дійсність релігійних об'єктів. Існує строге співвідношення релігії та релігійного об'єкта. Об'єкт породжує релігію. Різні релігії історичні явища, включені в хід суспільного життя, нерідко відходять від свого джерела. “Таким чином, - пише представник Страсбурзької школи Р.Мель, - релігійний об'єкт має свою власну структуру; він відрізняє себе як від релігійного досвіду, так і від історико-соціологічної структури релігії. За своєю природою він належить до “великих об'єктивностей”, що панують над нашим життям, i водночас відрізняються від конкретних історичних явищ. Можна також відзначити його схильність бути трансісторичною реальністю. Він претендує на те, що він завжди в історії, не будучи їі частиною”.

Розрізнення релігійного досвіду і релігійного об'єкта - специфічна особливість феноменології, що прагне запобігти психологізуванню віри. Інтенціональність у феноменологів - це не пізнання "зовнішності”, а спосіб існування свідомості. Об'єкт свідомості не “твориться", а осягається, усвідомлюється (після попередньої очистки). Бог $є$ іманентним свідомості, але ця іманентність не має психологічного характеру. Бог, що переживається - не образ, не елемент досвіду, а значення, норма; тому його дескрипція здійснюється в термінах “знаковості", “абсолютно іншого”, почуття благоговіння, святого тощо, а не в емпіричних атрибутах.

"Святе" у трактуванні Р.Отто стало взірцем релігійнофеноменологічного розуміння об'єкта. Він вважав, що раціональні засоби не можуть ні виразити, ні торкнутися божественного. Тому невдалими $є$ спроби підійти до почуття святого і релігійної свідомості взагалі зі звичайним понятійним апаратом, в тому числі гносеологічним чи етичним. Р.Отто вводить термін “нуменічний” (що означає божественне, надприроднє) для первинної характеристики святого, котре логічно не може бути проаналізоване і ні $з$ чим не пов'язане, тобто є автономним. Теолог не може визначити "нуменічне", він може тільки підготувати свого слухача до цілком самостійного його бачення. "Розумінню слухача можна допомогти, тільки пробуючи підвести його 
за допомогою роздумів до такого стану власної душі, коли вона сама зможе його пробуджувати, активізувати і змусити усвідомлювати”.

Подальший аналіз “нуменічного” Р.Отто пов'язує 3 його поглибленим безпосереднім спогляданням, що постає спочатку як “таємниця”, що викликає страх. Ця таємниця є парадоксальною й антиномічною, вона перевищує можливості людського розуміння $\mathrm{i}$ пов'язана з чимось “цілком іншим”. Водночас вона чимось притягує, манить людину, змушує іï відкликатися на неї, набуває рис святого. Відповідь людини на рівні первісної культури має шаманський характер, на більш високих стадіях цивілізації з'являється містицизм чи прагнення людини до єднання з Богом, інші релігійні форми.

У М. Шелера основу філософського підходу до релігії (і до будьякого антропологічного явища) становить феноменологія як спосіб споглядання, за допомогою котрого споглядаються сутності. Це споглядання можливе через участь у визначенні (за допомогою інтенції) сутнісних (чистих, феноменологічних) фактів як об'єктів пізнання, що не можуть бути опосередковані логічними символами й операціями. В феноменології “йдеться по-перше, про самі факти, що передують будьякій логічній фіксації, по-друге, про їх безпосереднє споглядання”.

М.Шелер вплинув на феноменологію релігії не тільки концепцією “чистих об'єктів”, але й розробкою одного 3 важливих аспектів проблеми інтерсуб'єктивності - “розуміння” через інтимне співпереживання 3 іншими. Його праця “Сутність і форми симпатії, присвячена обгрунтуванню того, що сутність іншого неможливо виразити в поняттях, але вона $є$ доступною для бачення тільки через любов, виявилась могутнім стимулом осмислення почуття страху, провини, благоговіння, святого тощо. Вони не набули статусу фундаментальних властивостей релігійного суб'єкта й мали імпліцитну вказівку на інтенціональні об'єкти цих почуттів, реальність яких втратила властивість індиферентної відчуженості від людини. Цим самим відкрились нові можливості розуміння Бога.

Феноменологи мають розв'язати “проблему”: чи Бог $\epsilon$ трансцендентним, а чи він $є$ іманентним? Спроби ії вирішення призвели до появи суперечливих припущень, які варіюють від припущення М.Шелером першосущного, первинно-духовного "пориву", до розуміння Ваардербургом релігії як "самовиразу людського існування". В релігійному акті, власне, долається протилежність іманентного і трансцендентного. Але для розуміння цього феноменологія релігії пропонує своєрідну концепцію не тільки об'єкта, а й суб'єкта релігійної свідомості.

При всій багатоманітності тлумачень феноменологами об'єктів 
віри сфера релігійного усвідомлюється як похідна спонтанної конструктивної функції свідомості. Вона прояснюється завдяки феноменології.

Кожна наука прив'язана до певної системи значення. Зміщування цих систем веде до непорозумінь, одне з яких - необгрунтована віра в те, що наука може довести чи спростувати Бога. Бог з'являється у “зустрічі” суб'єкта зі світом, який принципово трансцендентний і тому невизначений. Заперечення трансцендентного рівнозначно запереченню людини. Сутність людини - обов'язковість бути, і саме ії буття $\epsilon$ доказом трансцендентного.

Таким чином, феноменологія релігії як галузь релігієзнавства дає можливість осмислити ті зрушення, що відбуваються нині у сфері релігійного життя i які пов'язані 3 формуванням нового типу релігійності: не формальне дотримання вимог культової практики, не моральний канон, освячений авторитетом Церкви, а сповідування релігії як переживання трансцендентного смислу, прихованого безпосередньо в людській історії, коли завданням Церкви постає передача досвіду цього переживання.

Аналіз основних концепцій сучасної феноменології релігії доводить правомірність започаткованої Е.Гуссерлем феноменологічної критики історизму та прогресизму в підході до духовної культури, бо останні породжують, по-перше, знецінення теперішності як таких матриць прогресуючої історії, що не мають самостійного значення; подруге, різко критичну позицію щодо минулого (як такого, що “ще не доросло" до сьогодення), і, по-третє, співвіднесення 3 вигаданим майбутнім.

Сучасні феноменологічні дослідження релігії демонструють методологічну вагомість культивованого феноменологією заново народжуваного "подиву" перед реальністю як певного способу безпередумовного ii усвідомлення, що суперечить “призвичаєності". При такому підході сенс релігії (і культури взагалі) постає як особисте творче відтворення іiї глибинного, символічно вираженого змісту. При цьому символ виступає єдино можливою формою трансцендентного; в релігійній символіці об'єктивоване максимально можливе здійснення досвіду релігійної віри й пов'язаних з нею вищих людських прагнень.

Надання онтологічного статусу таким фактам людського існування, як віра, любов, краса і т. д., що поєднується з винесенням смисложиттєвого центру поза межі розірваної людської самості, може служити людині опорою й захистом від утисків та ідеологічних маніпуляцій, відкриваючи нові горизонти комунікації та подолання відчуження. В цьому полягає гуманістичний зміст феноменологічних 
досліджень.

\section{РОЗДІЛ 6}

\section{ПСИХОЛОГІЯ РЕЛІГІЇ ЯК ДИСЦИПЛІНАРНЕ УТВОРЕННЯ}

Науковий підхід до вивчення релігії формується у XIX столітті, коли релігія стає об'єктом самостійного дослідження, а останнє 3 необхідністю спирається на емпіричний матеріал та об'єктивні факти. Надзвичайно важливої ваги тут набуває принцип “відмови від посилання на трансценденцію”, або “методологічний атеїзм": дослідник, визнаючи факт реальності релігійних уявлень, залишає питання про їх істинність для теології чи філософії, що означає виведення “за дужки” дослідження питання про істинність або хибність існування предмету віри (Бога, богів, духів). Значна увага починає приділятися об'єктивному аналізу наслідків релігійності людини, впливу релігійності на особисте життя і життя суспільства. У межах наукового релігієзнавства (кінець XVIII - початок XIX ст.) виокремлюються такі напрямки:

- порівняльно-історичне дослідження релігії як історичного феномену;

- праці в галузі антропології та етнології, що наголошують на вивченні етичних норм і моральних уявлень у різних релігіях;

- соціологія релігії, головний предмет якої - соціальна обумовленість релігії, іiі роль і функції у суспільстві, в житті окремих суспільних спільнот;

- психологічний підхід, що оформлюється у кінці XIX століття, головним чином завдяки працям У.Джеймса, У.Вундта, а в подальшому - Е.Дюркгейма і З.Фрейда.

Предметом психології релігії виступають індивідуальні почуття, що пов'язані з релігією, віднайденням віри, а також вплив релігійного досвіду на поведінку індивіду, груп людей. Головний вектор досліджень психології релігії, як наукової дисципліни, має напрям від психології особистості, пошуків психологічних засад, особливостей релігійності, до соціально-психологічного аналізу та вивчення механізмів релігійності, їх наслідків у житті людини та суспільства. В цілому під психологією релігії розуміють окрему галузь психології, яка досліджує психологічні і соціально-психологічні фактори, що обумовлюють особливості релігійної свідомості, іiі структуру та функції, а також пояснює поведінку віруючих в цілому та представників окремих 
релігійних груп зокрема. Вивчення законів формування, розвитку i функціонування релігійної психології проводиться в кількох напрямках:

1. загальна теорія психології релігії - досліджує зміст і структуру релігійної свідомості, специфіку релігійних почуттів, психологічні функції релігії у духовному житті особистості і суспільства;

2. диференціальна психологія релігії розглядає релігійну свідомість і почуття віруючих 3 врахуванням конкретного середовища соціальної й історичної доби;

3. психологія релігійних груп вивчає соціально-психологічну структуру релігійних спільнот, механізми спілкування, наслідування, навіювання, установок та їх вплив на свідомість, почуття і поведінку віруючих;

4. психологія релігійного культу досліджує вплив релігійних обрядів на психіку;

5. педагогічна психологія релігійного виховання розробляє принципи формування релігійної свідомості.

Незважаючи на виняткову важливість зазначеної проблематики для розв'язання духовно-моральних проблем України, лише в окремих галузях наук про людину маємо публікації з цієї теми. При вивченні психології релігії у вітчизняній психології ще донедавна домінувала природознавчо-наукова орієнтація, а філософсько-релігійні концепції розглядалися в аспекті їх боротьби і “поразок” з матеріалізмом. Однак слід визнати, що багато психологічних проблем та ідей, що знаходяться у центрі уваги сучасної психологічної науки, були вперше запропоновані i розроблялися саме вітчизняними філософами i богословами. До них належать питання проблем особистості, соціальної справедливості, спілкування і конфліктів, психічного здоров'я та деякі інші. Досвід постановки і вирішення цих проблем заслуговує на увагу i має велику цінність для дослідження теоретичних і практичних проблем сучасного людинознавства. Останнім часом з'являються праці, що виконані на межі філософії, соціології i психології, в яких підкреслюється актуальність і необхідність подальшого наукового осмислення й аналізу зазначеної проблеми. Існує досвід використання ідей вітчизняної духовно-моральної релігійної традиції у практичному плані, зокрема у царині психотерапії і духовно-морального виховання молоді. Накопичені цікаві ідеї про зв'язок психології з християнством. 


\section{РОЗДІЛ 7}

\section{КОНСТИТУЮВАННЯ ЕТИКОЛОГІЇ РЕЛІГЇ̈}

В структурі релігієзнавства назріла необхідність, поруч із такими ii класичними дисциплінарними утвореннями як філософія релігії, соціологія релігії, феноменологія релігії, психологія релігії, конституювання нового напрямку теоретичного знання - етикології релігії. Як філософська дисципліна про релігійну мораль, етикологія релігії осмислює, узагальнюе, систематизує історичний розвиток релігійної моралі, історію iї становлення та розвиток, обгрунтовує природу, сутність, специфіку, функції релігійної моралі, закономірності ii розвитку й функціонування у різноманітті іiі конфесійних та конкретно-історичних форм вияву.

Етик досліджує основи людських поглядів і моральних позицій, зокрема те, чим людина намагається їх обгрунтувати. Інакше кажучи, етика цікавить діяльність людини, а також сформована цією діяльністю позиція і зрештою сама людина як суб'єкт своєї діяльності і позиції $з$ огляду їх моральної цінності. Етика - це теорія вчинку під кутом іiі морального обов'язку. Виходячи з цього твердження, під етикологією релігії будемо розуміти філософську теорію морального обов'язку діяння, де головним критерієм виступає відповідність Божому слову i єдиним джерелом моралі є Бог. Бог у релігійній свідомості визнається фундаментальним першопринципом порядку. Стосовно соціального порядку, Бог постає як законодавче начало, від якого є похідними всі інші принципи та норми людського буття. Як верховний регулюючий принцип, він не дозволяє соціальному життю втратити гармонійні форми. Встановлюючи, на думку віруючих, духовно-моральний порядок, Бог являє собою вищу, абсолютну досконалість, втілення того морального ідеалу, до якого повинна прагнути людина. Як абсолютна особистість, Бог $є$ втіленням абсолютного ступеня моральності. Люди не мають права змінювати моральні закони чи пристосовувати їх до своїх інтересів, тому що це $\epsilon$ сфера, над якою вони не владні. Зневажання цих законів веде за собою розплату - або в цьому, або в потойбічному світі.

Відтак для етикології релігії мораль - це співвідношення між вчинком людини і тим критерієм, в світлі якого окреслюється значимість вчинку. Мораль завжди $\epsilon$ феноменом не особистим, а соціальним. Адже обговоренню і оцінці підлягають швидше наслідки дій на основі переконань, а не самі переконання норми, цінності. 
Майже всі суспільства мають визнані стандарти етичної поведінки, які забороняють одні дії i дозволяють інші. Кожне суспільство має свої особливі етичні стандарти. Етика певної релігії формувалася в конкретних історичних умовах, для конкретного народу, а для іншої нації вона вже може й не підходити. Про моральність або аморальність релігійної людини, як, втім, і будь-якої іншої, правомірно говорити тільки 3 позицій певної, конкретної системи моральних цінностей (зокрема, мораль християнина дечим аморальна 3 позиції послідовника ісламу і навпаки). У протилежному випадку, всі розмови про моральнісні або аморальнісні дії носять лише схоластичний характер.

Відзначимо, що як на рівні буденної, так і теоретичної свідомості існують досить спрощені уявлення про характер взаємодії релігії i моралі, про сутність цих явищ. Нерідко трапляються спроби фактичного ототожнення релігії і моралі. Моральний елемент релігії все більше посилюється і висувається на перший план. Зрештою релігія нині постає насамперед як система санкціонування моральних вчинків, а не як засіб спасіння душі в потойбіччі. Відбувається антропологізація і гуманізація релігії. Головне в сучасних релігіях - «людські» проблеми, а саме: яка специфіка людського буття? яке місце людини в світі? які іï перспективи? який найвищий сенс людського буття? як людині слід жити, щоб здійснити своє призначення?

В релігійній свідомості містяться специфічні поняття, яких немає в моралі (Бог, сатана, пекло, рай тощо). Крім того, деякі поняття набувають в релігії особливе забарвлення, свою спрямованість. Так, поняття вини нерідко подається під виглядом поняття гріха, тобто як порушення Божого припису. Культова діяльність теж зумовлює певний вплив на моральне життя віруючого. Богослужіння, індивідуальна молитва здатні каталізувати моральні переживання, загострювати інтерес до смисложиттєвих питань. Однак формальне відношення до релігійного культу без належного переживання й усвідомлення знижує моральні пошуки, а в ряді випадків виникає лицемірство обрядодіяння, нігілілістичні і релятивістичні настрої.

Сдність походження моралі і релігії зовсім не засвідчує їхню нерозривність і абсолютну взаємозумовленість. Не стільки мораль має потребу в релігії, скільки релігія має потребу в моралі як засобі свого збереження й поширення. Релігія в різних іiі конфесійних виявах (а особливо християнство) поза мораллю існувати не може, чого не можна сказати про мораль. Будь-яке релігійне діяння так чи інакше пов'язане 3 моральними установками. Мораль як така не походить від релігії i, певною мірою, від неї незалежна. Вона може бути самоцінною й 
існувати цілком повноцінно без релігії. Релігійна мораль ж нав'язує норми, вони набувають характеру постулатів, аксіом, яких необхідно дотримуватися неухильно. Віруюча людина тільки тоді визнається моральною, коли вона відповідає цим нормам, причому в тому контексті, що пропонує ій та чи інша релігія, конфесія. Водночас людина, моральність якої не підпорядкована індивідуальним релігійним переконанням, має можливість реалізувати свою свободу вибору. Релігія цього вибору не дає. Вона обмежує цей вибір релігійними догматами, які і $є$ тими межами, у рамках яких й дозволений вибір. Але за цей вибір людина несе відповідальність, яка уже розписана в конфесійному віровченні.

На відміну від етики релігії, що завжди носить нормативний характер, етикологія релігії за своєю суттю виступає дескриптивною наукою про релігійну мораль. Нормативна структура релігійної моралі визначається характером і змістом норм, з яких вона складається. Ці норми мають наступні ознаки:

- виходять 3 вищого, абсолютного релігійного авторитету, яким $\epsilon$ Бог, Вчитель, ідея надприродного;

- мають характер абсолютних, безапеляційних вимог, правил та заборон;

- диктують певний внутрішній стан душі (віру), а також відповідну зовнішню поведінку;

- поширюються тільки на представників певної конфесії;

- мають своєю передумовою «страх Божий» у віруючого, якщо він не виконує їх, а також «суд Божий» як покарання за їх порушення.

\section{РОЗДІЛ 8}

\section{СОЩІОЛОГІЯ РЕЛІГЇ̈ В АРХІТЕКТОНІЩІ РЕЛІГІЄЗНАВСТВА}

В структурній архітектоніці релігієзнавства одне з важливих місць займає соціологія релігії. Знаходячись в тісному взаємозв'язку 3 філософією, історією, психологією, феноменологією релігії, культурологією та етикою, вона водночас постає як специфічна галузь загальносоціологічного знання.

В історичному аспекті перші спроби соціологічної рефлексії релігії мали місце ще в епоху Відродження. В подальшому соціологія релігії генетично була пов"язана з розвитком соціальної філософії, загальної соціології, 3 різними філософськими течіями, зокрема 3 
іменами французьких енциклопедистів (Ш.Ф.Монтескьє, Ф.М.Вольтер, Ж.Ж.Руссо, Д.Дідро, П.А.Гольбах), а також 3 філософськими традиціями, започаткованими І.Кантом, Т.Гоббсом, Д.Юмом, а пізніше Г.В.Ф.Гегелем, Ф.Шлейєрмахером, Л.Фейєрбахом, К.Марксом та ін.

Як галузь соціологічного знання, соціологія релігії конституювалася в першій половині XIX ст. і пов"язана 3 іменем Огюста Конта (1798-1857), який вважається засновником соціології як науки і якому належить пріоритет введення в науковий обіг самого терміна "соціологія". О.Конт, який в загальносоціологічному контексті досліджував взаємозв'язок суспільства і релігії, іï місце і роль у житті соціуму, започаткував позитивістський напрям соціології релігії. Цей напрям в подальшому розвивав Г.Спенсер.

Значний внесок у розвиток соціолоії релігії був зроблений К.Марксом (1818-1889). Він по суті вперше показав, що релігія за своєю природою є соціальним феноменом, вказав на земну, екзистенціальну, історичну іiі базу. Релігія, на його думку, постає як надбудова над економічним базисом суспільства, тісно вплетена в канву суспільних відносин, коріниться в соціальних структурах і виконує цілком реальні функції в житті людей, задовольняє широкий діапазон їх духовних потреб.

Глибокі дослідження релігії як суспільного феномену, іiі функціональних особливостей, що постають як соціально затребувані в контексті необхідності забезпечення солідарності, інтеграції соціуму, його цілісності, були проведені Е.Дюркгеймом (1858-1917). Релігію він трактував як специфічний і разом з тим як універсальний соціальний факт. Ї̈ї коріння він бачив у суспільному бутті людей. Е.Дюркгейма по праву вважають основоположником соціології релігії, структурнофункціонального методу ії дослідження.

Фундатором соціології релігії як галузі релігієзнавчого знання справедливо визнається i М.Вебер (1864-1920). Він є одним із засновників порівняльного підходу в соціології релігії. Вебер розробив цілу низку важливих як в теоретичному, методологічному, так і в практичному відношенні проблем, що стосуються взаємодії релігії і суспільства.

Функціональну здатність релігії М.Вебер вбачав у раціоналізації людської діяльності, в забезпеченні смислового навантаження останньої. Релігію він розглядав передусім як фактор соціальних змін, як невід"ємну складову частину соціального процесу. Вперше в соціології релігії М. Вебер переконливо довів існування безпосереднього зв'язку між релігійно-етичними принципами i 
формами економічної діяльності, показавши те, як етика протестантизму стимулювала дух підприємництва, “дух капіталізму”.

Значний внесок у розробку важливих проблем, методології соціології релігії, іiі конституювання і подальший розвиток як важливої галузі соціологічної і релігієзнавчої науки зробили А.Радкліф-Браун, Е.Трельч, І.Вах, Г.Ле Бра, Б.Маліновський, Е.Еванс-Прічард, Т.Парсонс, Р.Мертон, К.Леві-Строс, Р.Белл, Д. Белл, П.Бергер, Т.Лукман, Т.Керер, Ч.Глок, Р.Старк, Дж.М.Інчер, С.Булгаков, М.Бердяєв, М.Драгоманов, М.Грушевський, С.Токарєв, Д.Угринович, І.Яблоков, В.Танчер, О.Онищенко, А.Єришев, М. Закович, П.Косуха, А.Колодний та ін.

Хоча й сьогодні в соціології релігії, як у жодній галузі іншого гуманітарного знання, теоретичний аналіз здійснюється в межах методології, підходів певних шкіл, традицій, науково-соціологічних напрямів, які тією чи іншою мірою базуються на методологічних засадах, розроблених К.Марксом, Е.Дюркгеймом, М.Вебером, Т.Парсонсом, варто зауважити, що все це постає як єдиний потік соціологічного осмислення релігії. Наявні різноманітні, теоретичні концепти соціологічної рефлексії релігії, дискутуючи, взаємодоповнюючи одна одну, дають в кінцевому результаті багатоплановий (хоча нерідко контрадикторний за висновками) зріз релігії як соціально-функціонуючого феномену. Соціологія релігії, як i будь-яка наукова галузь знань, самовизначається щодо специфічної для неї і відносно самостійної множини взаємопов"язаних проблем, які піддаються соціологічному осмисленню. Йдеться про предмет або точніше про предметне поле соціології релігії.

Аналіз соціологічних теорій релігії як вітчизняного, так i зарубіжного походження, як академічного, так i теологічного спрямування, засвідчує неоднозначність, розмаїття підходів, поглядів, думок щодо визначення предмету соціології релігії. При цьому суперечки точаться, як правило, навколо того чи іншого формулювання предмету. Одні дослідники акцентують увагу на структурнофункціональних особливостях релігії в соціальному просторі іiі буття, інші - гіперболізують інституціональний чи антропологічний аспекти або не ототожнюють предметне поле цієї галузі релігієзнавчого знання 3 конкретно-соціологічним аналізом релігії в соціальних і особистісних координатах iï вияву. Джерела плюралізму тлумачень предмету соціології релігії - в складності, багатоаспектності, недостатній науковій опрацьованості такої специфічної (в соціальному прочитанні) проблеми, якою $\epsilon$ релігія, в труднощах системних уявлень про неї. Якщо інтегрувати наявні підходи 3 цього питання, то предметне поле соціології релігії можна було б охарактеризувати як комплекс проблем, 
базовими серед яких $є$ релігія і суспільство в різноманітності їх взаємозв'язків, взаємодії та взаємозумовленості. Предмет тут характеризується за допомогою ключових понять "релігія" i “суспільство".

Розшифрувати запропоноване визначення можна так: соціологія релігії вивчає релігію як суспільне явище, як невід'ємний елемент структури соціуму в різних аспектах і рівнях його соціального вияву. В цьому контексті предметом соціологічної експлікації постає релігійний феномен як реальний соціальний факт, як підсистема суспільства. Елементи структури релігії (релігійна свідомість, релігійні відносини, релігійний культ, релігійна діяльність, релігійні організації та інститути) в їх внутрішньозумовленому i суспільно детермінованому взаємозв'язку, а також у тісній співвідносності з іншими компонентами структури суспільства, форми, наслідки їх взаємодії також попадають в поле соціології релігії. Соціологія релігії включає у своє предметне поле i процес становлення розвитку, функціонування релігії, причини, фактори, детермінанти що покликали іiі до життя, а також iii інституалізацію, напрями і форми діяльності релігійних організації, роль і місце релігії в системі суспільних відносин, механізм іiі взаємодії 3 багатомірним соціокультурним простором.

Таким чином, йдеться про значний масив взаємопов'язаних проблем, що входять до предметного поля соціології релігії, аналіз яких уможливлює рефлексію соціологічних, соціокультурних, історичних, а почасти й антропологічних аспектів складної в структурно-змістовому контексті діалектики соціально-релігійної взаємодії.

Отже, соціологія релігії має свій предмет, свій кут зору на проблеми свого предметного поля. Вона, властивими їй методами, через систему специфічних (“ключових" і допоміжних) понять і категорій вивчає соціальну сутність релігії як “історичної реалії”, як “еволюціонуючої універсаліі”, релігійно-соціологічні форми i утворення, їх функціонування.

Соціологія релігії має два рівні осмислення зазначених проблем: теоретичний і емпіричний. Перший дає можливість дослідити релігію як цілісну, складну за своєю структурою систему, як соціальну підсистему, виявити іiі діалектику, взаємодії з іншими підсистемами суспільства. Йдеться про базові фундаментальні положення, що розкривають сутність релігійного феномену в його соціологічному прочитанні. Другий - характеризує систему конкретно-соціологічних методів, операційно-інтерпритованих понять, емпіричних узагальнень, що дає змогу з'ясувати сутність проблеми феномену релігійності як на макро (суспільство, географічні регіони, конфесії, демографічні групи), 
так і мікрорівні (особистість, невеличкі групи віруючих). Предметом дослідження стають релігійна свідомість, релігійна поведінка віруючих, релігійна діяльність церковних інститутів, організацій, конфесійно орієнтованих політичних партій, релігійна мотивація поведінки людей в усіх сферах суспільного буття тощо.

На емпіричному рівні соціологія релігії досліджує також ступінь, характер, динаміку релігійності, весь діапазон відношення людей до релігії, проблеми, що стосуються правового поля діяльності релігійних організацій, механізми реалізації права на свободу совісті, віросповідання, церкви, а також проблеми державно-церковних відносин, міжконфесійних взаємин, динаміки, стану i характеру релігійної ситуації в суспільстві. В межах єдиної наукової дисципліни, якою $є$ релігієзнавство, соціологія релігії використовує повний категоріальний набір так званих базових (загальносоціологічних, філософських) компонентів (понять, категорій, методів). Характерними є казуальний, структурно-функціональний, інституційний, конкретносоціологічний підходи. Зауважимо, що для сучасної соціології релігії як в Україні, так і за іï межами, характерними є плюралізм методів, принципів, тим більше, що соціологічний дискурс не витримується чітко в межах однієї традиції чи школи. Спостерігається тенденція взаємозбагачення парадигмальних установок, концепцій, понять, методологій та інструментарію дослідження релігії як соціального феномену.

Отже, соціологія релігії, специфічна складова галузь загальносоціологічної і релігієзнавчої науки, має свої традиції, власну теоретичну, методологічну та емпіричну базу, свою мову, своє поле проблем, центральною в якому є релігія і іiі суспільно-функціональний вияв.

\section{РОЗДІЛ 9}

\section{ЕТНОЛОГІЯ РЕЛІГЇ̈ ЯК ГАЛУЗЬ РЕЛІГІЕЗНАВСТВА}

Етнологія релігії як відносно нова й окрема галузь релігієзнавства, що виникла в результаті міждисциплінарного дослідження етносу i релігії, вивчає різні аспекти їх взаємодії. По-перше, в рамках етнології релігії вирішуються термінологічно-семантичні проблеми: як визначати i який смисл вкладати в поняття етносу i релігії, етнічної релігії, національної релігії, національної церкви тощо. По-друге, ця наука розглядає онтологічний статус етносу і релігії, тобто те, як можливе 
існування релігії та етносу в їх взаємозв'язку та взаємодії. По-третє, етнологія релігії ставить і вирішує питання того, чи $\epsilon$ релігія неодмінною, органічною ознакою етносу і чим $\epsilon$ (в структурному відношенні) релігія щодо етносу і етнос щодо релігії. Досліджуючи функціональність релігії та етносу, етнологія релігії, по-четверте, займається проблемою походження і початків цих двох феноменів: чи вони одно-, а чи різночасові. По-п'яте, з'ясовується вплив релігії на формування етносу і навпаки (як етнос формує свою релігію і які зміни вносить в чужі, приймаючи останні як свої). По-шосте, етнологія релігії визначає ті закономірності, за якими розвиваються етнос і релігія у своїй взаємодії. I останнє, етнологія релігії має спрогнозувати перспективи взаємозв'язків і взаємовпливів етносу і релігії на майбутнє.

Як бачимо, предметне поле етнології релігії є дуже широке. Воно, власне, включає весь сукупний релігійний досвід певних етнічних спільнот, тобто їх релігійні уявлення та релігійну практику, зафіксовані в історії етносу та його релігії пам'ятки матеріальної та духовної культури, що відображають появу i розвиток, природу і характер етнорелігійного зв'язку. Якщо коротко, то етнологія релігії вивчає релігійні аспекти життєдіяльності етносів та етнічні особливості релігійного буття окремої особи-носія певної етнічності або загалом етнічної спільноти. Відтак етнологія релігії покликана виявляти i вивчати взаємозумовлені, складні й суперечливі зв'язки етнічного та релігійного життя.

Релігія та етнос - явища, які, незважаючи на відмінність своєї природи, тісно пов'язані між собою онтологічно, історично, функціонально. Цей зв'язок настільки глибокий і тривалий, що постає питання про релігію як одну із етнічних ознак народу. Але, розглядаючи взаємозв'язок і взаємозалежність релігії і етносу, слід усвідомлювати, що ці явища відмінні. Релігія, як ніякі інші суспільні феномени, що виступають суто природними вимірами людської дійсності, відображає трансцендентні сфери буття людини. Вона $\epsilon$ ірраціональним вираженням вищого щодо людини буття. Етнос же - не надприродне явище, а результат взаємодії різних складових у процесі природного творення певної спільноти людей, які пов'язані різними нитками в соціально-економічній, культурній, географічній та інших сферах. Якщо релігія покликана наблизити, пов'язати людину з Богом, то в рамках етносу людина пов'язується з подібними до себе людьми свого племені, народності, нації. Як бачимо, онтологічні основи буття людини в релігії та етносі - відмінні. Вони не можуть заміщувати один одного і навіть не $\epsilon$ рівнопокладеними. Етнос і релігія різноплощинні: етнос - природна, соціальна, культурна, навіть економічна одиниця, релігія за своєю 
суттю $є$ трансцендентним явищем.

Під час етногенезу, на відміну від націогенезу, релігія постає одним із найважливіших компонентів цього процесу. Вважається, що всі релігії $є$ етногенетичними, бо їх поява і розвиток відбувався в рамках певного соціального, в т.ч. етнічного, організму, який витворював й свою релігію, культ, специфічну форму колективного чи індивідуального усвідомлення, переживання трансцендентного, форму вшанування та поклоніння йому. В первісних суспільствах релігія стала єдиною зримою формою виявлення етнічного. Саме в релігії фіксуються конкретні культурні досягнення етнічної спільноти, а відтак і рівень їі розвитку. В первісну епоху існували тісні зв'язки між релігією та етносом, між плем'яними культами та плем'ям, серед якого вони були поширені. Тому $є$ всі підстави говорити про збіг в той час релігійного та етнічного, про їх тотожність. Релігія виступає засобом вираження плем'яної (протоетнічної) належності.

Релігійні уявлення у кожного народу своєрідні, відмінні від інших, тісно пов'язані з їх етнічною картиною світу. Це тому, що релігія фіксує в понятті Бог результати пізнання світу, самої людини, весь (на перших порах) духовний (і не тільки) досвід етносу. Відтак релігія дає не тільки універсальні, а й перш за все етнічні форми осмислення людиною глибинних основ буття. Кожному народові характерне своєрідне сприйняття трансцендентного, через призму якого етнос організовує та відтворює світ.

Зростаючи разом 3 етносом, його релігія сприяє формуванню народу, інтегрує його завдяки спільній ідеології, єдиному віровченню, відправі культу тощо. Така релігія зберігає народ, його традиції, транслюючи їх 3 покоління в покоління. Як наслідок взаємодії релігійного та етнічного, формується етнорелігійність, яка відрізняє не тільки релігію від релігії, але й насамперед народ від народу. Тому належність індивіда до певної релігії виступає як його етнічна належність.

3 розвитком людства як етноспільноти зафіксований на початковому етапі збіг етнічного та релігійного поступово втрачається. В етнорелігієгенезі різних народів етнічне, порівнюючи 3 релігійним, довгий час $є$ визначальним чинником. Але з часом релігійне в людській історії починає домінувати, порівнюючи з етнічним, що стає вторинним і дещо несуттєвим. I лише у нові, а особливо в новітні часи етнічне бере реванш: відзначається сплеск національних рухів. В утворених секулярних суспільствах етнічне у взаєминах із релігійним набуває домінантного значення.

Якщо для етносу релігія, безумовно, є характерною ознакою, 
оскільки, як правило, кордони етнічного і релігійного збігаються, то для нації наявність релігії як ознаки не є обов'язковою. Це стосується особливо сучасних націй, скажімо, американської, де релігія (якась конкретна) не виступає національним критерієм. Навіть українців, які більш етнічно й релігійно гомогенні, ніж американці, не можна ототожнити з якоюсь однією релігією. На сьогодні жодний народ в світі не зберіг своєї релігійної однорідності. Людство перетворилось на багатоетнічну та полірелігійну спільноту.

Таким чином, онтологічний та історичний зв'язок між релігією та етносом, в результаті якого буття будь-якої релігії можливе і реальне лише в рамках певного етносу, де вона виникає, функціонує, трансформується, дає підстави вважати релігію певним етнічним індикатором народу. В такому разі в структурі етносу релігія не $\epsilon$ домінуючою, а лише доповнюючою складовою. Як правило, тут мова може йти не про релігію взагалі, а про конкретні іï конфесійні визначеності.

Етнос щодо релігії виступає необхідним грунтом (основою) для іiі виникнення, він $\epsilon$ тим полем реального буття релігії, де вона розгортає свої трансцендентні смисли. Релігія щодо етносу постає суперечливим, поліваріантним за своїм характером духовним важелем впливу, який виконує різні функції.

Відзначимо те, що етнорелігійні процеси у світі протікають за певними закономірностями, які притаманні всім релігіям і всім етносам. Це, насамперед, зумовленість того чи іншого типу релігій та етнічних утворень кліматом та географічним середовищем, в якому проживають людські спільноти. Від зовнішніх обставин залежить не тільки загальний фізичний вигляд представників етносу, а й характер їх ментальності, стиль і спосіб мислення, а зрештою - і типи релігій, зокрема активні чи споглядальні, пристосовницькі, світовтікальні чи світоопанувальні. Зрозуміло, що поява тих чи інших релігій спричинена стадією розвитку і рівня свідомості людини, іiі пізнавальними можливостями, глибиною осягнення нею світу земного i світу трансцендентного, що, природно, закладається національною культурою та традицією. Етнорелігієгенез залежить від ступеня соціально-економічної зрілості суспільства, який визначає швидкість, інтенсивність, напрямок, перспективи його поступу.

В процесі етнорелігієгенезу можна виділити дію одночасно двох тенденцій. Одна 3 них направлена на етнізацію (обетнічення або унаціональнення) людського суспільства та релігій, які в ньому з'являються, друга - на універсалізацію етнічного й релігійного життя людей, тобто деякою мірою на денаціоналізацію всіх сфер, в т.ч. і 
релігійної, людської діяльності. Як свідчать історичні факти, етнорелігієгенез протікає у відповідності до закону протидії, коли інтенсивність і результативність етнорелігійного розвитку пропорційні ступеню протидії йому. Чим сильніша протидія, тим вищий рівень розвитку, накал етнорелігійних змін, а чим вищий рівень, тим сильніша протидія.

Особливістю сучасних етнорелігійних процесів можна вважати те, що вони вже не відбуваються в рамках окремого народу, незалежно від інших етнорелігієгенезів. Останні тісно пов'язані між собою, тобто протікають і в горизонтальному, й у вертикальному вимірі. Це означає, що на етнорелігієгенез якогось народу безпосередньо впливають подібні процеси інших народів. Відтак етнічний і релігійний розвиток якоїсь спільноти все менше залежить від внутрішніх, іманентних даній етнічній одиниці причин. Він дійсно стає елементом загального, вселюдського етнорелігієгенезу, підпорядковується його законам, тенденціям, часовим вимірам. Сьогодні умовою здорового етнорелігійного розвитку є збереження i розквіт всіх етносів, а не асиміляція чи поглинення великими націями малих. Цілісність і цінність людства - в його етнічному і релігійному багатстві.

Характерною рисою сучасності $\epsilon$ різноманітність не тільки народів та релігій, а й багатоваріантність самого етнорелігієгенезу. Всупереч колись пануючій думці про уніфікацію всіх суспільних процесів, в тому числі й етнорелігійних, все більш популярною стає думка про неповторність історичного й екзистенційного досвіду кожного народу, який не можна схематизувати, бо збідниться багатство i унікальність шляхів реалізації глибинного потенціалу різних національних культур.

I останнє, етнорелігієгенез має незворотний характер. Ті зміни, які відбулися в етнічному і релігійному обліку світу, окремих народів, не можливо повернути. Тому будувати майбутнє людство як цілісність етнічних спільностей, не враховуючи при цьому їхню історію чи відроджуючи колись існуючі народи та їх релігії - нездійсненна мрія, політична утопія.

Протягом людської історії функції і роль релігії щодо етносів неодноразово змінювалися із-за складності етнічних процесів, які характеризуються не лише виникненням і розвитком етносів, а й їх занепадом та знищенням.Так, скажімо, компенсаторна функція релігії, яка щодо суспільства загалом постає як зняття у трансцендентному вимірі життєво важливих суперечностей і проблем людського буття, на рівні етносу виявляє себе як зняття тих проблем, які набули етнічних форм, i заміщення реальних проблем суто етнічного існування. 
Компенсаційна функція релігії щодо конкретного народу виявляється в тому, що вона, виводячи реальні цінності даного етносу із світу земного в світ небесний (сакралізація тутешнього життя) фактично заміщує їх у специфічній формі, відображає історичні і повсякденні умови його життя за допомогою релігійно-міфологічних символів, малює перспективи народу, дає надію нездійсненним сподівання пригніченого народу, чим, власне, виповнює реально неіснуючу рівність народу. Урівнюючи людей в рамках однієї етнічної спільноти, релігія в такий спосіб знімає гостроту соціальних конфліктів в суспільстві.

Якщо конкретизувати щодо етносу загальну світоглядну функцію релігії, яка задає граничні критерії людського життя, то релігія формує не лише універсальні світоглядні установки i, як правило, в етнічних формах, але й етнічно означену уяву про світ. В рамках етнічної релігії, де етнічна та релігійна картини світу збігаються, ця функція позитивна в частині збереження універсальних знакових комплексів, який виокремлюються через єдиний лексичний фон, що наявний в свідомості людини тієї спільноти, до якої вона належить. 3 появою в етнічному середовищі чужої для нього релігії виникає конфлікт між етнічною i новорелігійною картинами світу. $Є$ підстави стверджувати, що етнічна картина світу взаємодіє з релігійною, в результаті чого змінюються старі і утворюються нові синтетичні константи етнічного світогляду.

Виконуючи свою комунікативну функцію, релігія на загальнолюдському рівні постає як засіб зв'язку віруючих з Богом в рамках якогось віросповідання, конфесії, церкви. Ця ж функція щодо етносу $\epsilon$ домінантою у стосунках одновірців, яка грунтується на етнічній єдності, сприяючи зближенню і контактам єдиновірців.

Релігії характерна ще одна роль щодо етносу - інтегративна, завдяки чому забезпечується зв'язок, злагода, згуртованість одновірців. В рамках етнорелігій зв'язок етносу за віросповідною ознакою грунтується на кровному родстві. Із-за пріоритетності етнічного в етнічних релігіях останні краще інтегрують етнос, ніж світові релігії, для яких релігійні, а не етнічні цінності є домінантними. Етнічні релігії прагнуть до національної єдності і солідарності, в той час як світові релігії переслідують іншу мету - єдність релігійну, солідарність всіх народів, але за віросповідним принципом.Похідними від інтегративної $\epsilon$ етноформуюча, етноідентифікаційна, етноконсолідаційна, етнозберігаюча та інші функції релігії. В період зародження i утвердження етносу релігія виступає як інтегратор останнього, а на етапі життєдіяльності нації, особливо при загрозі для іï існування, релігія щодо етносів виконує зберігаючу роль. Згадаємо роль 
зороастризму в збереженні гебрів та парсів чи роль греко-католицизму в самозбереженні українського народу.

Релігія тоді є позитивною силою щодо етносу, коли повністю або частково вплетена в етнічну структуру народу, коли збігаються конфесійні та географічні кордони етнічної спільноти, якщо релігія i церква включені до національної культури, коли відбувається в масовій свідомості ототожнення конфесійної та етнічної належності через призму самоусвідомлення й самовідчуття за моделлю "українецьправославний”, “узбек-мусульманин”, “швед-лютеранин”, “бірманецьбуддист" тощо. Тільки в цьому разі можна говорити про виконання нею інтегративної функції. Але на сьогодні таких монолітних, релігійно гомогенних націй майже не лишилося. Абсолютизувати роль релігії щодо етносу виключно в інтегруючих детермінантах не слід, бо на стадії становлення нації або самозбереження вона може бути різною.

Будучи спрямованою на зміцнення однорідності якогось етносу, релігія виконує внутрішньоетнічну (або інетнічну) функцію, тобто цементує ядро народу, нівелює відмінності або розбіжності між наявними всередині нього субетнічними або етногеографічними групами. Виконуючи цю функцію, роль релігії зростає, оскільки повноцінна трансляція етнічного досвіду і традицій неможлива без залучення релігійних каналів. А це тому, що в релігії, особливо національній, закладена модель етнічної цілісності. В процесі консолідації етносу релігія утверджує іiї всіма своїми складовими. Так, культ задовольняє етнос в його зміцненні через виконання культових дій з хрещення дітей, весільних та поховальних церемоній тощо. Саме культ регламентує національну поведінку, зберігає ii етнічні стереотипи. Індивідуальна подія, багаторазово повторюючись серед етносу, забезпечує структурний ритм етнічного поля, маніфестує спільність історичної долі.

Розглядаючи роль релігії в етногенезі з точки зору лише іiі функціональності, ми свідомо відмовляємося зрозуміти релігію як активний і суперечливий фактор соціальних і духовних змін, зокрема як чинник етноісторії, етногенезу, етнорозвитку людства. Традиційно релігія подається виключно як похідне від породжуючого ії соціального середовища, а відтак як пасивний наслідок, а не причина локальних або глобальних суспільних, в т.ч. й етнічних, змін. Надаючи релігії лише консервативну, зберігаючу, тобто охоронну, функцію, ми сприймаємо іiі лише як надбудову над соціальними відносинами 3 дуже пасивною роллю в етнопроцесах. Якщо ж розглядати релігію як складову соціального процесу, тоді вона постає фактором соціальних змін, а не лише основою стабільності суспільства. Великі релігійні рухи мали 
значення для диференціації основних типів суспільства, для створення окремих етносів, окремих цивілізацій. Ідеї, які були закладені в цих релігіях, здатні були істотно зрушити традиційні суспільства, змінити світові парадигми і смисли людської життедіяльності, але за умови певної відповідності тієї чи іншої релігії смислопокладеній діяльності етносу.

Функціоналістська модель релігії однобічно підкреслює позитивний вплив релігії на етнос і недооцінює той факт, що він не завжди був поступальним, інтегративним. Часто релігія мала дестабілізаційний й асоціальний вплив. Більше того, одна й та ж релігія може слугувати цілям національної консолідації (католицизм в Польщі) чи сприяти асиміляції впливів з боку інших націй (католицизм в Чехії), а також може викликати етнічні конфлікти, а відтак й дезінтегрувати суспільство. Проте роль релігії не зводиться лише до функціональної чи дисфункціональної. Випадки, коли релігія виступає як фактор дезінтеграції, конфлікту, руйнування, не говорить про іiі негативну природу. Конфлікт на одному рівні може сприяти інтеграції на іншому.

Якщо оцінити роль релігії як сумарний результат і наслідок впливу на етнорозвиток людства, то вона є важливою, а в деякі періоди історії - визначальною, проявляючись в діалектиці своїх амбівалентних значень. Наукове з'ясування ролі релігії передбачає комплексність: 3 одного боку, релігія виступає інтегративним фактором, який підтримує стабільність етнічної системи і загалом суспільства; з іншого - релігія $\epsilon$ джерелом перемін в соціальній сфері, які одночасно викликають зміни і в самій релігії.

\section{РОЗДІЛ 10}

\section{ПОЛІТОЛОГІЯ РЕЛІГЇ̈: СТАНОВЛЕННЯ І ЗМІСТ}

В руслі філософії і соціології їх представниками ще в XIX столітті був закладений міцний фундамент академічному релігієзнавству взагалі $\mathrm{i}$, зокрема, такому його структурному елементу як політологія релігії. У подальшому в XX столітті на цій основі складалися і поступово еволюціонували політологічно-релігієзнавчі концепції i теорії у західному релігієзнавстві.

Зрозуміти процес становлення політології релігії як галузі академічного релігієзнавства не можна без визначення самого терміну “політологія релігіі", який до широкого наукового вжитку в релігієзнавчій сфері увійшов лише наприкінці XX століття. Він 
складається з двох слів - політологія і релігія. Політологія (має грецьке походження: "політікос" - державні, суспільні справи і “логос" - слово, поняття, вчення) - це наука, що вивчає політику та ії̈ зв'язки, взаємодії, опосередкування, взаємовідношення з особою і суспільством, досліджує відносини між соціальними суб'єктами щодо здійснення (завоювання, розподілу, використання) політичної влади. Політологія, як i релігієзнавство, сформувалася в окрему галузь суспільно-гуманітарного знання на грунті соціології. Тому не випадково стосовно політології в зарубіжній і вітчизняній літературі часто вживається ще термін політична соціологія. Структуру сучасної політології складають: загальна політологія (досліджує історію і теорію політики), теорії середнього рівня (їх предметом є влада, політична система, політичні процеси, політичне лідерство, політична духовність, політична культура тощо) i спеціальні політичні науки (політичні історія, географія, антропологія, психологія, соціологія, семантика, етнографія та ін.). Правомірно буде віднести до спеціальних політичних наук i політологію релігії.

Таким чином, можна констатувати, що політологію релігії однаковою мірою можна розглядати як структурний компонент двох важливих галузей суспільно-гуманітарного знання релігієзнавства (яке досліджує релігію як суспільний i особистісний феномени) та політології, що мають спільне наукове коріння. Політологія релігії взаємодіючи 3 структурними компонентами як політології, так i релігієзнавства, перебуваючи у їх системі вивчає зв'язки між релігією i політикою, владою, політичною системою суспільства, вплив релігії, релігійності, релігійної культури і духовності на прийняття політичних рішень, на формування політичної культури і духовності, на політичний вибір та соціалізацію особистості і навпаки, досліджує співвідношення релігійних і політичних відносин, діяльності, свідомості, моралі, виховання тощо. Відтак, політологія релігії акумулює досвід і знання, 3'ясовує закономірності щодо функціональної взаємодії політики i релігії, які накопичувалися впродовж всього часу існування людської цивілізації.

В сучасних умовах українського буття вчені-релігієзнавці проводять глибокий аналіз структурного i функціонального рівня взаємовпливів релігії і політики, простежують еволюцію теократичної ідеї походження влади, розглядають богословські концепції релігії і політики, визначають основні моделі взаємодії держави і церкви та дають їм характеристику, аналізують державно-церковні відносини в Україні. 
Значна кількість їх праць присвячена проблемам державноцерковних відносин, міжконфесійним конфліктам та їх профілактиці і попередженню, аналізу релігійно-політичної ситуації в Україні, взаємодії релігії і політики, релігійним інституціям як суб'єктам внутрішньополітичного процесу та релігійному чиннику у виборчому процесі, визначенню ролі релігійної складової у практиці українського державотворення та політиці України щодо релігії в контексті трансформацій сучасного світу, аналізу здобутків світового досвіду державно-релігійних відносин, прогнозуванню наслідків зрощування релігії і політики та глобалізації і вестернізації релігійного життя., визначенню чинників, що в сучасних умовах детермінують загострення проблем національної, державної та духовної безпеки, релігійнополітичним трансформаціям в контексті глобалізаційних перспектив майбутнього. Тут можна порадити прочитати вже видрукувані Відділенням релігієзнавства ІФ НАНУ п'ятнадцять чисел щорічника «Релігійна свобода».

Відтак, політологія релігії - це молода галузь академічного релігієзнавства, що межує 3 політологією і має глибоке історичне коріння та помітні перспективи подальших досліджень своїх проблем. В своєму розвитку вона відбула певні історичні етапи і набула наукового оформлення в незалежній Україні завдяки наполегливій праці українських вчених-релігієзнавців.

\section{РОЗДІЛ 11}

\section{ПРАВОЛОГІЯ РЕЛІГІЇ В ЇЇ ПРЕДМЕТІ ТА СТРУКТУРІ}

В структурі комлексного релігієзнавчого знання все більшої актуальності ( в теоретичному і практичному вимірі) набуває нове дисциплінарне утворення - правологія релігії. Воно постає однією 3 важливих у континіуумі тих наукових дисциплін, що творять, образно кажучи, архітектоніку сучасного релігієзнавства: філософія релігії, історія релігії, соціологія релігії, психологія релігії, феноменологія релігії, етнологія релігії, антропологія релігії, правологія релігії. Щодо самого терміну (назви дисциплін) «правологія релігії», то він $є$ певною мірою умовним, оскільки за своїм змістом не покриває все предметне поле, що має науково опікуватися цим дисциплінарним утворенням. У більш широкій «диспозиції» раціональніше було б використовувати термінологічні конструкти «юридичне релігієзнавство» (А.В.Пчелинцев) або «правові аспекти релігієзнавства». Однак у 
робочому варіанті будемо використовувати все ж термін правологія релігії, співвідносячи його 3 широкою сукупністю проблем, що підлягають експлікації цією релігієзнавчою дисципліною. Зауважимо також, що правологія релігії, як й інші релігієзнавчі дисципліни, грунтується на власній теоретико-методологічній основі, що взаємодіє i корелюється 3 іншими методологічними традиціями, взаємно збагачуючись і доповнюючи одна одну.

Відзначимо, що правологія релігії - це $є$ не просто результат певного суб'єктивного прагнення до продукування ще однієї наукової дисципліни в релігієзнавчому контексті. Це - об'єктивна необхідність. Вона детермінується гострою в теоретичному і практичному плані потребою системного наукового осмислення предметного поля правових проблем, що стосуються буття релігії як суспільного феномена і є невід'ємною частиною сучасного релігієзнавчого дискурсу. В цьому аспекті можна вести мову про своєрідне «соціальне замовлення» на спеціальний системний розгляд проблем права й релігії, а в їх взаємодії - юридичних основ свободи буття останньої. При цьому береться до уваги, що релігія постає як один 3 вагомих факторів суспільного буття людей i «утворює інститут», що нерозривно пов'язаний $з$ основами людського існування, в його соціальному і правовому аспектах, в площині взаємодії релігії (іiі інститутів), віруючих, держави, суспільства, їх взаємовідносин і взаємовпливів.

Звідси постає й необхідність глибше пізнати природу взаємозв'язку права і релігії: а) внутрішнього комплексу релігійних канонів, норм і приписів в їх регулятивній сутності, в спільнотному та індивідуальному вимірі; б) світських правових імперативів, які мають відношення до зовнішнього вияву буття релігії в суспільстві, релігійної діяльності. Раніше ці проблеми експлікувалися в філософії, соціології релігії, юридичній науці. Це певною мірою обмежувало можливості поглибленого повноцінного, а головне - системного теоретичного їх осмислення.

Відзначимо у цьому зв'язку, що проблема співвідносності права i релігії в усіх іпостасях вияву була предметом уваги, зокрема, філософів, юристів 3 давніх- давен. I те, що ми сьогодні маємо в цій царині, $\epsilon$ надбанням майже трьохтисячолітнього періоду наукових пошуків, аналізу, рефлесії проблемних питань, зокрема, в площині «релігія і право». Ці питання в історичному контексті зароджувалися й осмислювалися в різних цивілізаціях (Індія, Китай, Іудея, Сгипет, Елада), а в подальшому синтезувалися із теологічними концепціями та стали цементуючою основою релігійних догм i правил, зокрема давньоіндійської, іудейської, християнської, мусульманської традицій. 
Історія дає нам масу фактів щодо тісного взаємозв'язку релігії і права, опосередкованого походженням останього із релігій як на Заході, так i на Сході [Див. детальніше: Тихонравов Ю.В. Судебное религоведение .-M.,1998. -C. 21-40].

Таким чином, правологія релігії має міцну теоретичну й практичну базу в історичному контексті, в значному масиві філософських і правових, політологічних і теологічних праць, в т.ч. і в теоретичних напрацюваннях останніх десятиліть [Тихонравов Ю.В. Судебное религоведение -М.,1998; Клочков В.В Религия, государство, право. - М,.1979; Морозова П.А Государство, право, религия // Актуальные проблемы современного права. - М.,1995; Козлов Т.П. Религиозная правовая традиция (теоретический аспект). - М.,2008; Рабинович С.П. Права людини в природно-правовій думці католицької церкви. - Львів, 2007; Релігійна свобода. Науковий щорічник Вип. 1-14.К., 1996 - 2009; Ярмол Л.В. Свобода віросповідання: юридичне забеспечення в Україні. - Львів, 2006; Права человека и религия. - М., 2001; Пчелинцев А.В. Свобода религии и права верующих - М.,2004].

Обсяг напрацювань - значний. Їх аналіз засвідчує поліаспектність i багатогранність предметного поля правології релігії. Воно постає як дериват об'єкта, яким у теоретичному і практичному сенсі опікується правологія релігії. В цій площині остання експлікує сукупність суспільних відносин ( в усіх іпостасях їх вияву), які складаються в процесі функціонування релігії, релігійної і світської правових традицій в їх взаємозв'язку, взаємодії і взаємокорелятивності. Можна з певною вірогідністю констатувати, що саме об'єкт, яким системно і комплексно в науковому плані має опікуватися правологія релігії, постає водночас $\mathrm{i}$ структуроформуючим останньої. В цьому аспекті йдеться про два важливих компонента архітектоніки правології релігії: а) всю сукупність релігійних правових норм, приписів, що по суті конституюють як внутрішне, так і зовнішне (в публічному вияві) релігійне право як своєрідну конституцію конфесій, норм. Релігійне право є одним з основних історичних форм права, як «форма найбільш узгодженої взаємодії релігії і права», специфічного синтезу релігійних і юридичних норм, приписів, що постають як своєрідний імператив у житті віруючих, релігійних спільнот, їх інститутів; б) матрицю світських правових норм, відповідних законодавчих актів, конституційних положень, інших нормативних приписів (легітимізованих державою), що стосуються сфери державної політики щодо релігій, і церкви ( релігійних організацій), забезпечення свободи буття релігії в суспільстві. 
Щодо предметного поля правології релігії (юридичного релігієзнавства), то воно охоплює релігійні і юридичні закономірності формування i розвитку релігійної правової традиції, релігійних правових систем в їх конфесійному вимірі, релігійних передумов світського права, релігійні і світські правові інститути в їх взаємозв'язку, а також світські законодавчі акти, які стосуються публічної сфери буття релігії, свободи діяльності релігійних організацій, державно-конфесійних відносин, їх законодавчого забезпечення, теоретичних основ свободи віросповідання, церкви (релігійних організацій), правових механізмів їх гарантування i забезпечення .

Предметне поле правології релігії, нагадаємо ще раз, $\epsilon$ поліаспектним. Його експлікація потребує опрацювання категоріальнопонятійного апарату, зокрема, таких понять як: «релігійно-правова традиція», «релігійне право», «канонічне право», «внутрішньо-церковне право», «зовнішне публічне релігійне право», «державно-конфесійні відносини», «церковна дисципліна», «правовий статус релігійних організацій», «свобода віросповідань», «свобода церкви», «свобода в релігії», «свобода совісті, релігій, церкви», законодавства щодо забезпечення свободи буття релігії в суспільстві тощо. Правологія релігії (юридичне релігієзнавство) постає, таким чином, як важлива галузь релігієзнавчого знання, що дозволяє осмислити широку у своєму вияві проблему взаємозв'язку релігії і права в його конфесійному вияві, релігійної правової традиції, внутрішніх і зовнішніх релігійно-правових регуляторів буття релігійних організацій, а також об'ємного пласту законодавчого забезпечення світською державою свободи функціонування релігії, церкви (релігійних організацій) в суспільстві, правових аспектів цього буття.

\section{РОЗДІЛ 12}

\section{КУЛЬТУРОЛОГІЯ РЕЛІГІЇ ЯК СФЕРА РЕЛІГІЄЗНАВСТВА}

Специфікою наукового релігієзнавства є орієнтація його змісту на забезпечення не тільки нагромадження раціональних знань про релігію і релігійну культуру, але й прилучення до цінностей, що мають загальнонаціональне значення, формування і розвиток соціального досвіду, світоглядної, культурної і суспільної ідентичності. Культурологічний підхід до феномену релігії потребує з необхідністю синтезу всіх існуючих гуманітарних підходів, а також системного 
аналізу релігії як складової універсуму культури у всьому різноманітті внутрішніх зв'язків, що існують в культурі. Культурологічний підхід вирізняе інтегративність, міждисциплінарність, спроби дослідження релігії та ії зв'язків з культурою як єдиної системи й особливого класу явищ. Культурологічний підхід до релігії відкриває нові можливості розуміння ролі цього феномену в культурі. Він грунтується на принципах об'єктивності, раціональності, науковості. Культурологія релігії базується насамперед на нормах наукового доказу, обгрунтування, переконливості, міжгалузевої наукової методології і методики.

Структура релігії й культури не збігаються в абсолюті, але, безумовно, корелюють між собою. Сучасні дослідники фіксують тенденції зростання впливу релігії на всі сфери соціального життя. Власне в духовності шукають і знаходять найбільш ефективні інструменти для пояснення соціальних процесів. А релігія, безсумнівно, належить до цієї сфери культури.

Об'єднання описового, історичного, нормативного, психологічного, структурного і генетичного підходів до феномену релігії, на наш погляд, дає можливість говорити про предмет і метод культурології релігії. Також до цього ми додаємо функціональний аналіз, антропологічний, онтологічний і етнографічний підходи.

У культурологію релігії повертається раціоналістичність, далека від будь-якої містики за визначенням, хоча й покликана ії пояснити. При дослідженні релігії й культурі треба звернути увагу на те, що світ це єдність. Нема винятково матеріальної і винятково духовної культури. Розсікаючи заради теоретичної зручності культуру на матеріальну i духовну, варто пам'ятати, що ми при цьому одержуємо надто сильні абстракції, які не дозволяють, наприклад, зрозуміти цілісність будьякого ідеалу як тотожності суб'єкта й об'єкта, матеріального і духовного, почуттєвого і надчуттєвого.

Існують три основні моделі ролі релігії в культурі. Відповідно до першого, релігія $\epsilon$ генотипом культури, саме вона визначає культурний фенотип, усю духовну і матеріальну розмаїтість національного та транснаціонального буття. Тому кожна окрема культура іменується за релігію, що породила i живить іï (християнська, буддійська, мусульманська та інші культури).

Діаметрально протилежною є “світська модель”, відповідно до якої культура виростає зі зразків господарського життя народу. У такому випадку культури іменуються або виходячи 3 особливостей виробництва, торгівлі і споживання (збирання, землеробство, кочова або осіла культура), або за їхнім місцезнаходженням, географією. 
Різновидом даної моделі є марксистський економічний детермінізм, що виводить культуру з економічного базису. При цьому релігії надається допоміжна, надбудовна роль.

Третя модель культури $є$ спробою синтезу першої i другої моделей: генотип культури- це єдність релігійної духовності та економічних архетипів. Методологія цієї моделі грунтується на метафізиці Аристотеля (дійсність - єдність матерії і божественної форми), біблійної онтології (космос формується Богом 3 первісного хаосу) і діалектиці Гегеля (якість має ідеальну і речовинну сторони). Чим активніше впливає прийнята народом релігія на господарське життя, і навпаки, тим необхіднішим стає їх співіснування. Отже, через активну взаємозміну і зворотні зв'язки, релігія й економіка стають двома сторонами єдиної субстанції культури.

Висновувати це можна лише розуміючи, що це не статичні, а динамічні за своєю природою структури. Релігія як частина культури $\epsilon$ складною системою функцій i матриць (спосіб мислення, логіка, аксіоматика, аксіологія і т.д.), що змінюються у процесі історичного розвитку. В різні періоди історії релігія виконувала стосовно культури різні функції, становила різні іiі частини, різною мірою іiі репрезентувала. Як відзначає М. Пісманік, “релігійний початок найбільш стійке ядро національної культури в трагічні періоди історії етносу... Але разом з тим, неправомірно зводити національне в культурі лише до релігійного i, наприклад, ототожнювати духовне відродження нації із загальним воцерковленням" [Писманик М.Г. и др. Религия в истории и акультуре. - Пермь, 1995. - С. 171].

Глибоке засвоєння національної і світової культури неможливе без занурення в їх релігійні підстави. Щоб зрозуміти і відчути духовну субстанцію того чи іншого народу або міжнаціонального об'єднання, зовсім недостатньо ретельно вивчити їхнє матеріальне буття, важливо також проникнути в сутність їхньої релігії. Ми мало що зрозуміємо, наприклад, у культурах Індії чи Японії, якщо не звернемося до індуїзму чи синтоїзму. Таємниця культури народу багато в чому криється в його релігії.

На наш погляд, культурологічний підхід виділяє наступні основні характеристики релігії:

1. Релігія - змістовне наповнення як індивідуального духовного життя людини, так і спільного життя людей у групі, родині, соціумі.

2. Релігія - ненаслідувана біологічно інформація, виражена в культурі (світі створених людьми явищ). 
3. Релігія містить зразки людських відносин: способи сприйняття, відчування, мислення, поведінки, виражені в символічній формі.

4. У рамках різних релігій формуються різні технології: соціальної взаємодії, матеріальних об'єктів, породження і трансляції цінностей, символів, традицій і т. д.

Культурологічне дослідження релігії, як правило, припускає відслідкування "культурної біографії” релігійних ідей, обрядів, образів. На "макрокультурологічному рівні" це виражається у простежуванні трансформацій міфу, міфологічного сюжету, культурного героя і т.д. Крім того, окреслюючи контури культурологічного дослідження релігійного життя, варто було б розглянути культурну роль Церкви, відношення релігії до філософії, місце теології в культурі, співвідношення атеїстичних і релігійних ідей у культурному просторі, нарешті, співвідношення релігії з іншими культурними формами мораллю, мистецтвом, наукою, містичним у культурі тощо.

Суперечка про співвідношення релігії й культури велася у трьох напрямках, що базуються на різних аксіоматичних положеннях: перше релігія є основою і вихідною точкою культури (наприклад, у російських релігійних філософів), культура має надприродне джерело i $\epsilon$ породженням релігії, без релігії культури бути не може, вона втрачає зміст; друге - культура і релігія - принципово різні речі, більше того вони антагоністичні, і культура витісняє релігію як форму суспільного буття (така точка зору присутня у ранніх роботах Енгельса); третє релігія $є$ одним зі структурних компонентів культури, роль якого історично змінюється (наприклад, у Т. Парсонса).

Коли мова йде про структуру релігії, то мається на увазі, що стійкі елементи релігійної системи (норми, зразки, інститути, групи, культи i т. п.) перебувають у певному співвідношенні і взаємодії між собою, забезпечуючи стабільність релігійної системи, іiі відтворення, можливість трансляції не тільки релігійної традиції, але й культурного досвіду в цілому.

Спираючись на методологію структурно-функціонального аналізу (Т. Парсонс), у релігії як системі можна виділити чотири основні функціональні блоки: адаптивний, цілепостановний, інтеграційний та функції відтворення культури і зняття прихованих напруг. Ці функції має будь-яка релігія, тому їх можна вважати універсальними, але у певну ієрархію вони вибудовуються порізному, залежно від унікальних особливостей тієї чи іншої культури [Parsons T. Sociological theory and modern society. - N.Y-L., 1967. - S. 115]. 
Виходячи з ідеї Т. Парсонса, релігію необхідно розглядати як одну зі сторін системи людських дій, що піддається трансформації разом із розвитком культури й особистості, або як систему функцій, спрямованих на культуру. Останнє ж є наслідком того, що релігія, поряд 3 мовою, семіотичними знаковими системами і т. д., $є$ репрезентантом культури. При цьому не викликає сумніву, що зв'язок релігії і культури (як і зв'язок з останньою інших їі репрезентантів) у процесі історичного розвитку з'являється як складна система взаємозумовленостей [Американская социология. Перспективы, проблемы, методы / Под ред.. Т.Парсонса. - М., 1971. - С. 234]. Постійний пошук нових змістів як форма самовираження утворить своєрідну систему “залежностей”релігія адаптується до змін культури, викликаючи в ній нові зміни. Переривання цього процесу веде до радикальної перебудови системи культури чи до iї загибелі. Розвиваючи даний підхід і розглядаючи релігію як один з репрезентантів культури, можна через семіотичний зріз релігії визначити ступінь розвитку культури.

Якщо поняття “культура" i “релігія” логічно пов'язані відносинами частини і цілого, релігія є частиною культури, то аксіологічно - у сфері відносин цінності й оцінки вони рівноправні: не тільки релігія може бути оцінена 3 позицій культури, але й культура - 3 позицій релігії. П. Сорокін, наприклад, визначав культуру, як ”...єдність, або індивідуальність, всі складові частини якої пронизані одним основним принципом і виражають одну, і головну, цінність. Саме цінність $є$ основою і фундаментом будь-якої культури. 3 цієї причини найважливіші складові частини такої інтегрованої культури також найчастіше взаємозалежні: у випадку зміни однієї з них інші неминуче піддаються схожій трансформації' [Сорокин П. Человек, цивилизация, общество. - М.,1992. - С. 429].

Можна погодитися з релігієзнавцем І. Яблоковим, який відзначає: "Релігія, будучи складовою частиною культури, виконує культуротрансляційну функцію. Вона сприяє розвитку певних іiі складових - писемності, друкарства, мистецтва, забезпечує охорону i розвиток цінностей релігійної культури, здійснює передачу накопиченої спадщини від покоління до покоління" [Основы религиоведения /Под ред. И.Яблокова. - М., 1994. - С. 69].

Роль “міцного ядра" релігійної культури виконує основний священний текст (джерело певної релігії) 3 інтерпретаціями i традиціями. “Захисний пояс" культури творять світські ідеї, адаптовані до тлумачень прийнятих релігійних принципів і матеріалізуються у побутовій, виробничій, соціально-перетворюючій і науково-технічній практиці. Ці ідеї формуються у сферах моралі, політики, права, міфу, 
філософії, науки, економічної свідомості та в інших областях ціннісного ставлення до світу.

Слід зазначити, що останнім часом, намагаючись перебороти духовну кризу, культурологічна думка все частіше звертається до проблеми взаємозв'язку релігії і культури. Те ж робить і церква. Соціальні зміни сучасного світу, зміна напряму думок під впливом постмодерністських змін у культурі “ставлять під сумнів традиційні цінності”, в тому числі й релігійні, як це відображав II Ватиканський собор. У результаті все більше людей фактично відриваються від релігії, “стверджується гуманізм нового типу” [ПК, § 7]. Критикуючи “новий гуманізм", церква бореться насамперед проти марксистської концепції гуманізму і культури, і робить спробу збереження не просто релігійної культурної традиції, але й духовності як такої.

Релігія передбачає певну систему цінностей і моральних приписів, що складають модальні структури культури. Саме в ціннісному аспекті виражається зв'язок культури i релігії: остання як репрезентант культури, в насамперед, виконує функцію несення смислів. У такий спосіб релігія щодо культури може виконувати, й історично найчастіше виконувала, функцію формування нормативних меж, які забезпечують можливість існування, репродукування і розвитку культури, а, отже, суспільства.

У культурному житті нації надзвичайно важливим $є$ наявність культуротворчої ідеї. Якщо з якихось причин культура вичерпала свої духовні ресурси, вона вмирає. Довговічність нової культури буде залежати, на наш погляд, від того, наскільки повно нова ідея, нова віра, яка викликає цю культуру до життя, втілить у собі загальнолюдський зміст колишніх духовних традицій і який заряд новизни вона несе народу, що ії прийняв, і людству в цілому. Виробляючи фундаментальні ідеали, які складають духовний базис культури, релігія стає найважливішою формою збагнення єдності світу i зміцнення солідарності людей.

Культура, виходячи в сакральний вимір (виявлене у своєму світі, на основі своїх аксіом), звертається до реального релігійного досвіду, хоча реальність нашого часу така, що зараз важко уявити собі, що якась духовна сфера самостійно візьме на себе інтегруючу культурну роль. Релігія, релігійна культура, як правило, на це не претендує, однак, незважаючи на те, що іiї вплив на всі аспекти культури в даний час не настільки помітний, вона цілком зберегла всі свої функції i культуротворчі можливості, i це вибір культури - якою мірою цим скористатися. 
Релігія не завжди адаптується до змін у культурі і не завжди повинна це робити. Проте сьогодні ми спостерігаємо значний інтерес суспільства, культури до релігії, незважаючи на фактично узаконене вільнодумство, демократичність поглядів, плюралізм думок і авторитет науки. Сама історична реальність ставить завдання - прояснити, у чому полягають можливості релігії для людини, для культури в нашу епоху, яка змінює не тільки свідомість людей і умови їхнього існування у світі, але й сам світ. Тому необхідний серйозний аналіз антропологічних та онтологічних причин існування релігії, іï культурологічних можливостей. Силами тільки соціології, психології, філософії релігії це зробити дуже важко. Тому актуальним є культурологічний підхід до проблеми співвідношення й взаємодії релігії і культури.

Культурологічний аналіз дає можливість не тільки оцінити роль релігії у житті людства, але й глибше проникнути в антропологічну суть людини як суб'єкта культури. Він припускає інтегративність, необхідність дослідження релігії у іiї зв'язку з культурою як єдності, погляд на культуру як на цілісний організм. Тому, на нашу думку, розгляд релігії як складової універсуму культури необхідно проводити в контексті іï історичного виникнення i взаємозв'язку 3 іншими феноменами культури, суспільними процесами, історичною реальністю, етнічними особливостями народів.

Особливістю сучасної культури $є$ іiї транснаціональний характер, хоча процес формування загальнолюдської культури поєднується зі збереженням національного начала. Але глибоке засвоєння національної й світової культури неможливе без заглиблення в іiі релігійні засади. Тому необхідно всебічно проаналізувати вплив на відродження національної культури, духовний розвиток українців як нації. Адекватне розуміння взаємодії культури i релігії веде до порозуміння зв'язку релігійного і національного начал у культурі.

Релігія у сучасній культурі, як і в культурах попередніх епох, задає аксіологічні координати, ієрархію цінностей, сповіщає культурній діяльності вищу єдність і зміст. Можливості релігії у духовному відродженні України величезні насамперед тому, що у сучасному суспільстві релігія здатна зрівноважити граничну інваріантість як існування, так і смислів, цінностей культури. Саме цим пояснюється наш інтерес до проблеми взаємодії релігії і культури. 


\section{РОЗДІЛ 13}

\section{ІСТОРІЯ ТА ІСТОРІОСОФІЯ РЕЛІГІЇ: ПРЕДМЕТНИЙ ЗМІСТ І ВІДМІННІСТЬ}

Вираз “історія релігіï” зазвичай вживають у двох випадках: як означення реального процесу розвитку релігійного феномена і як назву галузі знання, що вивчає цей процес. У першому випадку наведений вираз охоплює зародження й еволюцію релігії в цілому чи окремих іiі елементів, напрямів, віросповідань; у другому - означає рефлексію зазначеного процесу та відмежовує в релігієзнавстві відповідну галузь останнього від інших його галузей - філософії, соціології, психології релігії, а в певному аспекті - від богословської історії релігії.

Сталося так, що через вузькість історичного кругозору історія релігії як наука зароджувалася переважно дедуктивно, в межах філософського знання. Навіть після того, як у XVIII-XIX ст. з'явились епохальні праці з історії культури (Дж.Віко, Ф.Вольтер, Г.Лессинг, Й.Гердер, Г.Бокль тощо), після ряду непересічних успіхів археології, етнографії, міфології, фольклору й мовознавства теоретична думка намагалася осягнути релігію передусім як таку (Г.Гегель, Л.Фейербах), а не як процес конкретної родоплем'яної, конфесійної тощо релігійності. В XIX - на поч. XX ст. інший підхід до історії релігії запропонували представники еволюціоністської школи (Е.Тейлор та ін.), що розглядали походження і розвиток релігії як наслідок психічної діяльності людини, намагання пояснити незрозумілі їй явища природи.

Врахування успіхів і недоліків згаданих підходів до з'ясування релігійного феномена, а також логіка протиборства релігієзнавчої i богословської думки висунули, зрештою, в наукових пошуках на чільне місце питання про буттійні основи релігії та іiі іманентні зв'язки. Питання це вирішувалося непросто й далеко не все в ньому достатньо 3'ясовано й зараз.

Захоплення відображувальною епістемологією релігійного процесу не сприяло пошуку відповіді на методологічно важливі питання: чи має релігія, крім відображуваного, власний зміст; чи повністю вкладається історія релігії в межі всесвітньо-історичного процесу, в його формаційні характеристики?

Пошуки відповіді на подібні питання нерідко пов'язувалися, особливо у західноєвропейській теоретичній думці, зі спробами збагнути сутність і прояви релігії методом інтелектуального дослідження, без конкретно-наукового та порівняльно-історичного аналізу релігій, поєднавши ідею саморозвитку релігії 3 апріорно- 
історичним підходом до неї та осмисленням історії релігії єдиним, закономірним процесом. У цьому напрямку, починаючи 3 Д.Юма, складається особлива галузь знання - “філософія релігії. В іiі формування великий внесок зробили І.Кант, Ф.Шлейєрмахер, Ф.Шеллінг, Г.Лессінг, Г.Гегель. Особливо велика заслуга в розробці проблем філософії та історіософії релігії належить Гегелю, що вперше обгрунтував розвиток релігійних вірувань як єдиний закономірний процес. Філософ окреслив притаманні історії духу стадії "природної релігії", "релігії індивідуальності” та “абсолютної релігії. Проте він не обмежився апріорно-схематичними міркуваннями, а послуговувався в характеристиці історії релігії віруваннями ескімосів, китайців, індусів, персів, єгиптян, римлян, християнськими віруваннями.

Відомі й інші численні спроби типологізаційного відтворення історії релігії. Зокрема, у західноєвропейській історико-релігієзнавчій думці генеалогічні групи релігії запропонував Ф.Гартман (релігія натуралістична i супернатуралістична, тобто абстрактного монізму i теїзму), К.Тіле (релігії природи та етичні релігіi) тощо. 3 певними застереженнями до історичної типологізації можна віднести й богословські класифікації релігії на язичництво і релігії одкровення, поганські і монотеїстичні релігії. Порівняно недавно відбулася й поширилася, передусім у марксистській літературі, рубрикація історичного процесу розвитку релігійного феномена на класифікаційні групи, що однозначно пов'язані з великими періодами суспільного розвитку й виходять із масштабу охоплюваних певними віруваннями етнічних спільнот. У такому випадку історію релігійного феномена репрезентують родоплем'яні, національні та світові релігії.

Здійснено немало й конкретних досліджень ранніх (найдавніших і давніх) і сучасних вірувань та культів багатьох народів світу (Е.Тейлор, Д.Фрезер, Л.Морган, Б.Малиновський, Л.Штернберг, I.Огієнко, В.Іорданський, С.Токарєв тощо.). Вони $є$ надзвичайно цінними для історико-релігієзнавчої думки, але не можуть, певна річ, виявити сутність і специфіку історії релігійного процесу. Все зрозумілішою ставала необхідність об'єднати філософський підхід із конкретними науковими дослідженнями релігії. На заваді такого об'єднання стоїть i досі не подолане до кінця переважання згаданого вище логіцизму при дослідженні минулого релігії (і релігій), а також надмірне захоплення “зовнішнім фактором” в іiі розвитку, що проявляється в гносеологізації історико-релігієзнавчої думки.

В академічному релігієзнавстві поширені описовий, збиральницький і більш широкий, теоретичний підхід до минулого релігії. Дослідження цього минулого покликане “описати й осягнути 
становлення релігії як в іманентних історико-релігійних зв'язках, так і в загальному соціально-історичному й історико-культурному контексті". У вирішенні цього завдання першорядну роль має відіграти філософія історії релігії, де помітно виділяються два шари - онтологічний, що дістав назву “історіософії релігіi”, і методологічний. Перший з них $\epsilon$ осмисленням сутності й сенсу реального процесу розвитку релігійного феномена, другий - репрезентує осмислення історії релігії як науки. Методологічний шар $\mathrm{y}$ дослідницькому аспекті постає через історіософію релігії і спільно з нею виступає сполучником історії релігії 3 філософією релігії - окремих дисциплінарних галузей академічного релігієзнавства. Як справедливо зазначав М.Бердяєв, об'єктивні історики чимало що можуть з'ясувати в проблемі джерел феномена, “але 3'ясування сенсу не дане історичній науці, це вже справа iсторіософії". Дійсно, “чимало що" не означає ні визначальних причин походження релігії, ні закономірностей іiі розвитку, ні сенсу іï власних якостей, іiі покликання. Тут слово залишається за історіософією релігії, якщо вона теоретико-методологічно забезпечує адекватність осягнення сутності й специфіки досліджуваного явища.

Нині історіософія $є$ осібною від філософії релігії галуззю академічного релігієзнавства, завдяки чому вона не зазнає напередвизначеності, як це мало місце в гегелівській філософії релігії, де історіософія була лише аспектом апріорно-дедуктивного філософствування щодо релігії. Якщо академічна історіософія (так ми іiі назвемо, на відміну від гегелівської, фейєрбахівської та й богословської історіософії) претендує на з'ясування сутності й сенсу реального процесу розвитку релігійного феномена, вона не може не живитися ідеями й принципами філософії релігії, що своїх розділів має метафізику, епістемологію й праксеологію релігії. Загальнотеоретичний зміст i методологічні засади цих складників філософії релігії, трансформовані відповідно сутності та специфіці історико-релігійного процесу, й становлять набуток філософії історії релігії, історіософії й методології - того “містка”, що з'єднує історичну й філософську галузі релігієзнавства.

Нагадаємо, історіософія має справу з сутністю і сенсом дійсного релігійного процесу в суспільній історії. Сутність історії релігії як категорія релігієзнавства виражає головне, закономірне в зародженні й розвитку релігійного феномена, зумовлене необхідними, внутрішніми зв'язками. Категорія “сенс історії релігії” $є$ визначальною в значенні і спрямованості руху релігійного феномена в контексті ідеалів і потреб

\footnotetext{
${ }^{1}$ Кимелев Ю.Н. Современная западная философия религии. - С. 164.

2 Бердяев Н.А. Истоки и смысл русского коммунизма.- М., 1990.- С. 10.
} 
віруючого. Сутність і сенс історії релігії - категорії, що сукупно виражають загальні властивості станів і форм історичного процесу релігійності як мислительно-фантазійного відображення й виповнення невільної діяльності людини.

Важливою проблемою історії релігії як галузі знання $\epsilon$ періодизація процесу розвитку релігійного феномена. Саме тут фокусуються, сходяться питання про сутність і сенс релігійного освоєння людиною світу, про походження вірувань і культу, причини, що зумовлюють зміни в них, про місце і роль релігії в суспільному й духовному процесі тощо.

Досі єдиної й добре аргументованої точки зору щодо критеріїв такої періодизації й характеристики самих періодів розвитку релігії ще немає. Чи не найбільш поширеною є точка зору, згідно з якою за основу вирішення проблеми береться соціальний, точніше - цивілізаційний фактор. При цьому послідовність станів розвитку вірувань і культу пов'язується 3 великими епохами в історії людства і насамкінець найчастіше набирає такого вигляду: релігії родоплем'яні, національні та світові.

Безумовно, цивілізаційний фактор відіграє детермінуючу роль в еволюційному поступі релігії. Без нього не можна зрозуміти ні сутності релігійних вірувань та культу, ні історичного розгортання й збагачення релігійного досвіду - від “природних" релігій до релігій одкровення. Дійсно, виникнення i розвиток історичних типів релігії, форм релігійності як пов'язаних між собою вірувань і обрядів у кінцевому підсумку зумовлені умовами життя ранньородового суспільства й формуванням основ понятійного мислення, переходом до продукуючого землеробства та розвитком первіснообщинного суспільства $з$ його міфологічним світорозумінням, появою додаткового продукту праці, соціальним розшаруванням, формуванням особистості та спробами усвідомлення нею свого місця в світі. Йдеться, отже, про “власну релігійність" суспільства як визначальну причину релігійної iсторіï.

Сучасні уявлення про роль ендогенного чинника у творенні історичних типів релігії мають ряд недоліків. Передусім, у них не має єдиного й виваженого критерію визначення етапів еволюції релігії - тут змішано “формаційний”, етнічний, геополітичний та ін. чинники. Тому й виходить, що до розряду, наприклад, родоплем'яних зараховують вірування, що склалися за різних історичних умов (напр., анімізм і віру в духів) й репрезентують якісно відмінні етапи в розвитку релігії; часом рівнодавні форми релігійної віри (як-от фетишизм і тотемізм) розташовуються на різних сходинках історичного процесу; до 
національних релігій відносять і вірування, що не вкладаються в одне історичне ложе (наприклад, давньогерманський культ плем'яних богівпокровителів і монотеїстичні вірування в іудаїстського Єгову); що ж стосується так званих “світових релігій", то їх "рубрикація" взагалі позбавлена формаційного чи етно-національного пояснення.

Проте головною вадою цивілізаційного принципу підходу до історії релігії є те, що в ньому буттєвий фактор абсолютизовано, не беруться до уваги межі залежності релігії від суспільного досвіду, а роль власного змісту релігії в іiі функціонуванні і розвитку не враховується. А тимчасом саме власний зміст (віра в надприродне, релігійні уявлення, почуття, поклоніння, релігійна функціональність) $\epsilon$ носієм сутності релігійного феномена, активним чинником творення його історичних форм, адже в ньому специфічно виражені інтереси, потреби, установки людини, тільки в ракурсі яких вона й “бере" дійсність. Якщо цей чинник випадає з поля зору, релігія постає у спрощеному вигляді - як відображувальна буттєвість, а інші іiі відношення (особливо виповнювальне, вірувальне й сублімативне) видаються за другорядні чи зовсім не заслуговують на увагу. Тоді суб'єкт-об'єктне релігійне відношення збіднюється до простої інтеріоризації зовнішньої данності, що лише "береться", а не перетворюється й підноситься до належного, яке знаходить найповніший вияв в ідеї надприродного. Це надприродне є серцевиною власного змісту релігії, через нього переломлюються зовнішні чинники, перетворюючись в ідеальне i, синтезовані в ньому, знаходять свою нову дійсність в історичних типах надприродного, в періодах еволюції релігії. Отже, за основу історизації релігії має стати двоєдність іiі власного змісту та буттєвих факторів, передусім епохальних чинників суспільного розвитку.

Якщо надприродне $\epsilon$ осереддям власного змісту релігії, то чинність його як фактора періодизації релігії має спиратися на певні критерії. Такими можуть бути: характер уявлень про зв'язок надприродного з природним, спосіб його уособлення, функціональність надприродного, сфера впливу на довкілля, вид сакрального практичнодуховного освоєння світу, тобто спосіб і форма входження віруючого в світ. Врахування цих критеріїв “рубрикації” розвитку уявлень про надприродне й буттєвих, зокрема етно-цивілізаційних детермінацій релігійності, дозволяє ставити питання про три історичні типи релігії: чуттєво-надчуттєвий, демоністичний і теїстичний.

Крім історії релігії як такої, для релігієзнавства великий інтерес становить конфесійна історія, історія церков, сект і деномінацій, релігійних рухів і вчень. Історично-конфесійна проблематика має не 
лише евристичну цінність для відтворення минулого різних релігій у конкретності їхніх форм, а й для з'ясування історії релігії в цілому, встановлення зв'язку іï еволюції 3 певними станами суспільного i культурного життя, зрештою - вона $є$ важливою умовою з'ясування природи, сутності і сенсу релігії як суспільно-історичного явища. Маючи власні предмет і методи дослідження (особливо порівняльноісторичний), історія релігії постачає іншим наукам інформацію про минуле й сучасне релігій народів світу, в свою чергу користуючись здобутками названих наук.

\section{РОЗДІЛ 14}

\section{ГЕОГРАФІЯ РЕЛІГІЙ ЯК РЕЛІГІЕЗНАВЧА НАУКА}

Географія релігій - одна 3 релігієзнавчих наук, що покликана вивчати просторову схему процесу виникнення i розповсюдження різних релігій, дати сучасну релігійну карту світу і статистичні данні поширення різних віросповідань, спрогнозувати перспективи змін конфесій у територіальній конфігурації їх діяльності. В рамках цієї науки досліджується роль природного фактору в появі і поширенні релігій певної конфесійної визначеності у різних країнах та континентах, розкривається автохтонність певних релігійних утворень тих чи інших географічних регіонів, 3'ясовується в історичній ретроспективі поява там інших релігій і відповідно доля місцевих течій, поширення світових релігій, розглядаються умови виникнення і шляхи можливого подолання міжконфесійного і міжрелігійного протиборства, виявляється взаємозв'язок етнічного і конфесійного в релігійній мобільності, проводиться картографування релігій. Відтак географія релігії - це теорія релігієгенезу, яка з'ясовує те, як і де виникають ті чи інші релігії, як природні фактори впливають на це, який існує зв'язок між географічними умовами та природою, сутністю і формами релігій, які історичні зміни відбуваються в релігійній карті світу, яка сучасна карта поширення різних релігій і який характер відносин між ними, які перспективи змін територіальних конфігурацій поширення релігій в світі.

Питання взаємодії природи і суспільства, природних факторів i такого суспільного феномену, як релігія, завжди цікавили дослідників, які по-різному підходили до розв'язання цих складних проблем. Відома концепція географічного детермінізму виводить появу релігій, як і будьякого соціального явища, з особливостей географічного середовища, 
ставлячи релігію в залежність від психіки людини, звичаїв, політичного та економічного устрою, що детерміновані саме природними умовами. Найяскравіший представник географічного детермінізму Е.Реклю вважав, що всі основні факти історії пояснюються географічними умовами тісї місцевості, де вони відбувалися.

На зміну географічному детермінізму прийшли ідеї детермінізму соціального, утверджуючи географічний нігілізм. Уникаючи двох крайнощів, треба визнати, що географічне середовище, будучи умовою існування людського суспільства, впливає на його розвиток. Багатоманіття географічних умов творить природну основу людської діяльності, в тому числі й духовної, результатом якої $є$ також і релігія. Прямо вивести залежність якоїсь релігійної системи від клімату певного регіону земної кулі було б явним вульгаризмом, але якщо вибудувати довгу череду зв'язків між релігією та географічними умовами іiі виникнення та поширення (острівним чи континентальним розташуванням країни, гірським чи рівнинним ऑii характером, особливостями клімату (суровий чи м'який), родючістю грунту, наявністю річок, морів, особливостями рослинного та тваринного світу, що впливає на направленість праці людей, а це в свою чергу визначає темпи історичного розвитку народів, розподіл праці і можливості існування спеціальної соціальної верстви, яка здатна продукувати, зберігати і вдосконалювати духовні цінності), то стає очевидним, як географічне середовище впливає на появу релігій, їх розвиток. Географічний фактор особливо велику роль грав на ранніх стадіях розвитку суспільства. 3 часом ця тенденція втрачається, чим, власне, можна пояснити існування в однакових природних умовах дуже різних країн, і навпаки - в різних природних умовах знаходяться однакові за суспільним устроєм країни. Як показує історичний досвід, більшість національних і світових релігій виникло у відносно стабільних (з точки зору взаємодії природи і соціуму) суспільствах.

Географія і релігії пов'язані між собою через етнос, взаємодію етнічного й конфесійного, виявлення яких - надто складний процес. Не просто відповісти на питання: чому серед одного народу поширена ця релігія, а серед другого - зовсім інша, чому народи Західної Європи прийняли католицизм, а Східної - православ'я, чому протестантизм масово поширився серед німців, а не серед французів, як впливає та чи інша етнічність на релігію, як, наприклад, китайці чи японці означили облік буддизму, і навпаки, як, скажімо, християнство трансформує африканську етнічність.

Кожний етнос виступає носієм певних цінностей, своєрідних культурних та психологічних ознак, мови, духовності, фізично-расових 
особливостей тощо. Формування цих характеристик у всій їх сукупності, серед яких помітне місце займають релігійні погляди, як в історії народу, так і в індивідуальному житті кожного 3 його представників проходить в певному середовищі, адаптивно адекватному тому чи іншому етносу.

Приймаючи концепцію Л.М.Гумільова про зв'язок i закономірність розвитку етносів та біосфери, в результаті чого формується механізм гармонічних взаємин людини з природою, етносу 3 навколишнім середовищем, можна прослідкувати зв'язок між розвитком релігій та географічним й етнічним середовищем та виявити збіг закономірностей в схемі появи і розвитку релігій та схемі появи i розвитку етносів. Ідея пасіонарності етносів рефлексує на пасіонарність релігій, оскільки ці періоди в історії людства дивно збігаються, тобто релігія якраз і ставала тим виходом, в який направлялась пасіонарність певного етносу.

Виходячи з ідеї еволюції людства, його культури як розвитку від нижчого до вищого, тотожності або подібності історичних шляхів різних народів та їхньої культурної єдності, наявності спадкоємності в процесі етногенезу, можна стверджувати, що i в релігієгенезі відбувається рух від нижчого до вищого. Різні релігії у своєму розвитку мають багато спільного, що наводить на думку про зв'язок різних релігійних традицій між собою, особливо в рамках якоїсь країни, якогось народу. В основі цього лежать особливості архетипів мислення i поведінки людей, що виявляють генетичні передумови і природні детермінанти в релігіях, в інших формах світобачення. Безперечним вплив релігії на характер народу і навпаки - псіхе народу визначає національні форми релігії.

Географія релігії подає загальну чисельність i розміщення послідовників найпоширеніших релігій в сучасному світі. Щодо першого, то статистичний облік віруючих - одна 3 найскладніших проблем як для дослідників, так і для самих церков. $\mathcal{C}$ церкви, які $з$ точністю до одиниці можуть назвати кількість своїх вірних. Це, як правило, протестантські церкви, в яких існує членство. Більшість церков лише приблизно визначають своїх прибічників за кількістю хрещень, сповідань, присутніх на богослужіннях тощо. Деякі церкви включають до своєї конфесії всіх вірних, в тому числі й дітей, інші лише так званих повних членів, певного віку. Як правило, церковна статистика тенденційна i прагне завищити реальні показники. Статистичний облік конфесійної структури суспільства існує в небагатьох країнах, оскільки вважається, що рахуючи вірних, держава порушує принцип свободи совісті. Навіть в найтоталітарніших країнах 
відмінений пункт про віросповідну належність їх мешканців. Будь-які статистичні данні страждають на неточність, хоч би тому, що в поліконфесійному середовищі важко віднести вірних до якоїсь певної конфесії. Як бути, скажімо, з "просто християнами", які фіксуються і як християни, і як православні, і як прихильники УАПЦ. В цьому випадку ïх рахують тричі. Хрестоматійним $\epsilon$ випадок з Японією, де віруючих (за переписом) виявляється майже вдвічі більше, ніж мешканців країни, бо ж оскільки вони одночасно відносять себе як до синтоїзму як національної традиції, так $\mathrm{i}$ до якоїсь конкретної конфесії християнського чи буддійського толку.

Не всі статистичні дані про послідовників різних релігій, які даються в різних джерелах, можна прийняти безумовно, оскільки в цих підрахунках часто $є$ певні похибки. Так, до іудеїв зараховуються всі євреї, хоч це не відповідає дійсності. Дані щодо буддистів, на нашу думку, дещо занижені, оскільки буддисти живуть у важко доступних районах, де й порахувати їх не можна. Карта поширення різних релігій в світі говорить про те, що серед 6-мільярдного населення планети десь біля 5 млрд. віруючих. Релігійна карта світу - це результат тривалого релігієпроцесу.

\section{РОЗДІЛ 15}

\section{КОНФЕСІОЛОГІЯ РЕЛІГІЇ ЯК РЕЛІГІЄЗНАВЧА ДИСЦИПЛІНА}

Долаючи первісне, досить загальне розуміння терміну "конфесія" як лише віросповідання (лат. confessio - визнання, віросповідання), сучасне релігієзнавство, спираючись на здобутки вітчизняної та зарубіжної наукової думки, а також практику застосування цього терміну, тлумачить поняття "конфесія" як офіційний системний виклад певної віросповідної доктрини, що може включати, як складові,

- основні положення віровчення (догми, символи віри), їх пояснення та аргументацію;

- історію віровчення та його утвердження, ставлення віросповідання до навколишнього світу, суспільства та інших релігій тощо;

- опис очікуваної світоглядної позиції, релігійної поведінки індивіда, який $є$ носієм даного віросповідання;

- втілення принципів віри у специфічну для даного віросповідання культову та обрядову практику, церковноорганізаційну структуру та ін. 
Прийняття даних віросповідних положень (догм), принципів та норм ідентифікує й об'єднує дану групу віруючих ідейно-догматично, організаційно-обрядово та морально-психологічно. Визнання i прийняття віруючим офіційно сформульованих положень певного віровчення фіксує конфесійна приналежність віруючого, робить православного - православним, католика - католиком, лютеранина лютеранином і т. д., відрізняючи його від прихильників інших конфесій.

Відомо, що найбільшу кількість конфесій породило християнство, переважно в реформаційний і післяреформаційний періоди. Сучасні релігієзнавці нараховують понад 150 офіційно визнаних віровчень i конфесій.

Потреба науково описати, пояснити, осмислити, вичленити закономірності, теоретично систематизувати, типологізувати об'єктивні знання про цілу низку значущих процесів та тенденцій, пов'язаних 3 офіційно затвердженою фіксацією фундаментальних положень певного віросповідання (конфесій), спричинила до появи в структурі релігієзнавства спеціальної галузі знань - конфесіології. Існуюча на сьогодні сума знань щодо предмета, функцій, методів конфесіології дозволяє визначити їі як галузь релігієзнавства, що

- займається дослідженням феномену конфесій як інституйованих віросповідних систем, які включають певне віровчення, його історію, культову та обрядову практику, організаційно-ієрархічну структуру як символічний відповідник даному віровченню;

- аналізує динаміку змін, що фіксуються конфесіями під впливом внутрішніх та зовнішніх чинників, політичних, соціальних та духовних умов функціонування віросповідання, трансформацій у позиціях самих віруючих;

- вивчає віросповідні спільноти індивідів, які ідентифікують себе 3 даною конфесією, поділяючи іiі ідеї, догми, обряди, організаційні засади та практичну діяльність;

- досліджує особливості функціонування конфесійних спільнот у державі, суспільстві, в середовищі політичних, соціальних, економічних, національних, культурно-освітніх та поліконфесійних об'єднань чи груп, а також взаємовпливи конфесійно солідарних спільнот віруючих та названих об'єднань і груп, їх структур;

- прогнозує стан і перспективи розвитку конфесійно єдиних спільнот із врахуванням існуючих тенденцій у суспільстві та самому релігійному середовищі, а також беручи до уваги прогнозовані внутрішні та зовнішні трансформації конфесій; 
- розробляє сучасні оптимальні методи вивчення конфесійних спільнот, явищ, процесів та закономірностей у них; формує нові, поглиблює вже усталені терміни, поняття, категорії, як специфічні для конфесіології, так і спільні з релігієзнавством.

Суто конфесійний аспект дослідження релігійних об'єктів визначає науковий предмет конфесіології як більш конкретизований, конфесійно маркірований, який в рамках релігієзнавчої науки більш детально, спеціалізовано досліджує явища і процеси конфесійного сегмента, збагачуючи, поглиблюючи зміст як самої конфесіології, так i релігієзнавства.

Принципово важливими напрямами наукових досліджень вітчизняної конфесіології $\epsilon$ проблеми історичного становлення найбільш чисельних конфесій, що склалися на християнському грунті в Україні, проблеми конфесіологізації в контексті суспільно-політичних процесів в Україні після XVI ст., функцій конфесій, їх класифікації, типологізації та ін.

В часописі «Релігійна панорама» №12 за 2008 рік видрукувано в тезовій формі тематично зміст можливого навчального курсу «Конфесіологія релігії».

\section{РОЗДІЛ 16}

\section{ГЕРМЕНЕВТИЧНИЙ АСПЕКТ РЕЛІГІЕЗНАВСТВА}

$\begin{array}{cccccr}\text { Наш час актуалізує включення герменевтики в } & \text { контекст } \\ \text { релігієзнавчих досліджень. Однак йдеться скоріше } & \text { не про }\end{array}$ герменевтичне релігієзнавство як одне 3 самостійних дисциплінарних утворень, а про герменевтичний аспект релігієзнавства. Під поняттям "герменевтичний аспект релігієзнавства" ми розуміємо включення, вписування власне герменевтичного інструментарію в релігієзнавчий матеріал.

Функціонування герменевтичних понять, ідей, принципів у контексті релігійної традиції насамперед пов'язане 3 еволюцією предмета біблійної герменевтики. Вперше герменевтична проблема в контексті християнської традиції була поставлена ще Орігеном в його четвертій книзі "Про начала". Нову сторінку в освоєнні герменевтичного арсеналу відкриває Августин Аврелій. Його "De doctrina christiana" по праву може слугувати за посібник з біблійної герменевтики.

На відміну від Августина представники Реформації відмовились 
від традиційного розуміння Святого Письма, що за своєю суттю означало апеляцію до авторитету. Вони висунули принцип тлумачення тексту Біблії з огляду на сам текст. У протестантській теології часів Реформації релігійна герменевтика набуває істотно нового значення. Йдеться насамперед про принцип контекстуального тлумачення, що вимагає при дослідженні тексту брати до уваги контекст. Це ставило смисл у залежність від контексту. У такий спосіб проблема багатозначності, для вирішення котрої святі отці доклали чимало зусиль, втрачала свою гостроту.

У теологічній спадщині XVIII ст. помітне місце займали розвідки відомого інтерпретатора Нового Завіту, теолога Йоаніса Ернесті. На його думку, герменевтика має виконувати два завдання - розуміння i, власне, пояснення. На думку дослідника, слід відмовитись від догматичної єдності канону. Відтак теологічна герменевтика в побудовах Ернесті заходить у логічну безвихідь. Праці теолога Й.Ернесті започаткували секуляризацію біблійної герменевтики, iii трансформацію в герменевтику історичну.

3 XVIII ст. розвиток герменевтики здійснюється у двох напрямках - філологічному й теологічному, що не суперечили у своїх методологічних засадах один одному, більше того, подеколи перехрещувались, взаємодоповнювались. Новий етап власне релігійної герменевтики пов'язаний з іменем Ф.Шлейємахера. Під герменевтикою він розумів мистецтво, завдяки якому існує можливість повторити творчий процес автора тексту, навіть відчути, усвідомити текст краще від авторського його розуміння. Релігійна герменевтика у Шлейєрмахера неначе розчиняється в універсальності. Відомим представником цього етапу філософської герменевтики був також німецький філософ Вільгельм Дільтей, що послуговувався герменевтикою як універсальним методом розуміння культури минулого.

Сучасний етап еволюції герменевтичних принципів у релігієзнавчих пошуках, так звана екзистенційна герменевтика, що ще має певний теологічний відтінок, репрезентована працями відомих діячів протестантської думки Рудольфа Бультмана, Ернста Фукса i Герхарда Ебелінга. Насамперед відзначимо ті загальні особливості, які характеризують специфіку теологічної герменевтики XX ст. Ними є: тісний зв'язок теологічної герменевтики 3 філософською герменевтикою; об'єкт дослідження залишається незмінним, традиційним, як, для прикладу, біблійні тексти; герменевтичним дослідженням властива антиеволюційність, антиісторизм у змістовному наповненні інтерпретацій. Прикладом герменевтично орієнтованої 
теології може слугувати теорія деміфологізації Р.Бультмана, викладену ним в книзі "Новий Завіт і міфологія. Проблема деміфологізації новозавітного благовістя".

Цей екскурс в історію проникнення герменевтичних інтуїцій, ідей, принципів у богословські концепції служить основою для побудови й реконструкції уявної моделі “герменевтичного аспекту релігієзнавства". Спочатку трохи про гіпотетичну реконструкцію понятійного апарату. Згідно з духом герменевтики, тут доцільно виділити два понятійні ряди: перший пов' язаний із становленням смислів релігійних феноменів і 3 осягненням смислу феномену релігії як безпосереднього об'єкта вивчення; другий пов'язаний із можливими інтерпретаціями, орієнтованими на розуміння загального смислу релігійних феноменів $\mathrm{i}$ їх смислових відтінків. Іншими словами, такі основоположні поняття релігієзнавства, як “релігія”, “Бог”, “людина”, “сакральне”, “релігійне почуття”, “Біблія” тощо мають входити як предикати в обсяг суб” єкта поняття “смисл”. Відповідно, всі вищеназвані основоположні поняття повинні служити об'єктами для найрізноманітніших “інтерпретацій”. При цьому родові поняття "смисл” та “інтерпретація" вихідною категорією мають поняття "розуміння", що, в свою чергу, може тлумачитись із психологічних, методологічних, культурно-історичних i навіть онтологічних позицій.

Принагідно зауважимо, що постійна дилема “істинністьнеістинність" в герменевтиці не працює. Для герменевтики (в тому числі й релігійно забарвленої) головним $є$ поняття автентичності, що зумовлює глибинну відповідність тексту, достеменно, іманентність йому. Тож замість істини в ній слід використовувати автентичність.

3 огляду на сказане, зробимо такі висновки:

1. "герменевтичне релігієзнавство” як окрему дисципліну науки про релігію неможливо осмислити, застосовуючи герменевтичнй інструментарій через функціонування принципу плюралістичності у тлумаченні основоположних понять релігієзнавства;

2. "герменевтичне релігієзнавство" існує лише як методологія. Йдеться про включення, вписування герменевтичного інструментарію в релігієзнавчий матеріал, тому доцільніше говорити про функціонування в методологічному відношенні “герменевтичного аспекту” релігієзнавства;

3. методологічно плідним $є$ виділення двох понятійних рядів герменевтично орієнтованого релігієзнавства, а саме: понятійного ряду, пов'язаного з з'ясуванням смислів релігійних феноменів, i понятійного ряду, пов'язаного 3 наявністю 
можливих інтерпретацій, що розкривають загальний зміст релігійних феноменів і їх смислові відтінки.

\section{РОЗДІЛ 17}

\section{ПРАКТИЧНЕ РЕЛІГІЕЗНАВСТВО ЯК НОВА ДИСЦИПЛІНАРНА СКЛАДОВА ФАХУ}

Українські релігієзнавці - спочатку в житті, а тепер i в дослідженнях - започаткували нову сферу релігієзнавства - практичну. I це не тому, що вони не мають бажання входити в метафізичні хащі філософії, історіософії чи психології релігії. Цим аж ніяк не піддається сумніву практичну значимість праць філософів чи психологів релігії. Більше того, практичне релігієзнавство активно користується їхніми працями. Але їх дослідження зорієнтовані не на нові умоглядні словоплетива щодо релігійних феноменів, а насамперед зорієнтовані на оприсутнення релігії в суспільстві, від якого вона аж ніяк не відокремлена, хоч й відокремлена від держави. Кожний віруючий, як i будь-яка релігійна інституція, водночас $є$ і не від світу цього і в цьому світі. Ось тут якраз і пролягає та межа, яка різнить теоретичне $\mathrm{i}$ практичне релігієзнавство. Останнє, власне, саме й покликане відтворити реальні шляхи входження віруючого і релігійних інституцій в світ. Це передбачає дослідження шляхів цього входження насамперед через взаємодію сакральних (церковних) і світських інституцій (в т.ч. й 3 державою), через перебирання на себе рядом релігійних організацій світських форм діяльності, через міжконфесійну взаємодію, а не протистояння, через підключення до вирішення складних проблем нинішнього українського соціуму різних міжнародних релігійних спільнот тощо.

Бути практичним релігієзнавцем значно тяжче, ніж теоретиком релігії. Ти тут щодня маєш справу 3 живою і часто неочікуваною ситуацією, із сформованою століттями міжконфесійною упередженістю i водночас незнаними релігійними новотворами, із прагненнями окремих спільнот лише себе розглядати як релігію ( до того ж єдино істинну), а інші віросповідання - як єресь. Релігієзнавець-практик постійно зустрічається із фактами необгрунтованої заангажованості 3 боку державних чиновників різного рівня (від президента країни до голови сільради) на певні (а то й лише одну) Церкви чи релігійні течії і водночас всіляким протистоянням (часто антизаконним), 
адмініструванням, бюрократизуванням щодо інституцій інших конфесій.

То ж, як бачимо, практичне релігієзнавство визначає своє дослідницьке поле не за рахунок негативного, опортуністичного ставлення до релігієзнавства теоретичного. Воно, поруч 3 ним, має право на своє існування. Але не рахуватися 3 тим, що в наш час відбувається зміщення інтенцій осмислення релігійних явищ, зміна тематичних і концептуальних орієнтацій релігійних спільнот, ми не можемо. Відходить те бачення релігії, яке сформувалося в епоху модерну. Релігія сама відчуває вже якусь свою непотрібність, незапрошеність. Сьогоднішній віруючий виштовхує іiї на окраїни свого життя і свідомості. Він розміщує іiі ще в своєму побуті - домашньому i почасти громадському, а в інші сфери - iі не допускає, бо ж не знаходить їй там місця.

Але справа не тільки в тому, що сьогоднішній віруючий нині переважно невоцерковлений. Визнаємо, що він дотримується переважно етикету своєї релігії, а не іiі етики. Визнаємо і те, що значною мірою вже не працюють Заповіді Мойсея в своїх установках не красти, не вбивати, не чинити перелюб, не заздрити на майно ближнього та ін. Я не говорю тут про Заповіді Блаженства Ісуса Христа: вони в повному своєму обсязі (за незначним винятком) взагалі ніколи не були життєві. В наш час порушено також довіру до науки, бо ж маємо процвітання позавіросповідної містики, окультизму, іншого духовного хламу. Але ж це - також релігійність. Вона не є традиційною, але вона стає масовою, базуючись на народних суєвір'ях. Народ вже перестав вірити в якесь заступництво і допомогу історичних Церков. I якщо віруючі старшого віку із-за традиції, просто звички ще відвідують їхні храми, то молодь значною кількістю пішла до харизматів, де знаходить сучасні засоби i для спілкування, i для задоволення своїх пізнавальних інтересів, i для задоволення художніх потреб в нових формах. У всякому разі, вона не сліпа і бездіяльна маса глядачів (як у храмі традиційної конфесії), а активна спільнота релігійного життя. То ж епоха постмодерну вимагає вивільнення від якихось стандартних, віками усталених форм боговшанування. Вона актуалізує питання творчого богомислія i богодіяння. Церква, якщо вона хоче бути “запрошеною”, має у відповідних формах відповідати на ці виклики часу.

Відтак, як бачимо, практичне, значно урізноманітнене нині ставлення віруючого до світу, те практичне релігійне мислення, що супроводжує його, стають відокремленими релігійними феноменами, а відтак - окремими об'єктами осмислення. Саме це й спонукає нас виокремити в релігієзнавстві його практичне дисциплінарне утворення. 
Перш ніж розглядати детально його зміст, згадаймо принагідно виокремлення Кантом “практичної філософіі”. У німецького філософа знаходимо два модуси застосування розуму - технічно-практичний i морально-практичний. Не станемо тут вникати в деталі розмірковувань німецького філософа, але відзначимо те, що для Канта індикатором достеменної практичності (практичного розуму) поставала свобода. "Практичне є все те, що можливе завдяки свободі", - зауважує він.

Так ось для практичного релігієзнавства однією із вихідних його категорій постає саме категорія свободи совісті. Ця свобода сама по собі $\epsilon$ безумовною і абсолютною. Вона постає як практичне апріорі. Лише така свобода, а ми ії всіляко прагнемо утвердити в українському соціумі i в цьому виявляється наше діяння як практичних релігієзнавців, виступає не як щось зовнішнє, нав'язане особистості, а як щось внутрішне, трансцендентне, само собою зрозуміле. Формуючи дійсне розуміння свободи совісті, ми цим прагнемо спонукати кожного віруючого, незважаючи на його конфесійну належність, піднятися над собою, своєю релігійною заангажованістю, по-іншому прочитати ті відомі слова з Біблії, коли Бог засвідчує, що єдиною його ознакою $є$ лише те, що він $€$, тобто просто оголошує своє буття. А якщо це так, то тоді будь-який конфесійний поділ, будь-яке обрядове оформлення релігії - не від Бога, а від людини. То чого ж із-за цього, наголошуємо ми конфесіям, вступати в якісь битви і конфесійні протистояння. Якщо Ісус Христос вчив любити не просто ближнього, а передусім ворога свого, то хіба є християнським явищем міжконфесійна ворожнеча або зневага до інаковіруючої чи взагалі невіруючої людини. Визнаймо право кожного на свій шлях до Бога, свої форми його вшанування і це буде виявом реального гуманізму.

Відтак свобода совісті - це повага до гідності кожного, а саме на власній гідності й розвивається особа в епоху постмодерну. В громадянському суспільстві, яке ми будуємо, кожна особа постає сувереном. Відповідно цьому має змінитися (як католики кажуть аджонаментуватися) і релігія. Можливо й ми, релігієзнавці, в цьому в дечому можемо підказати їй. Ми, релігіє знавці, вже десь 3 десяток років наголошую, що якщо християнство не змінить свою парадигму гріховності і покарання за неї на парадигму моральної величі Ісуса Христа, Христа як морального ідеалу, то саме із-за цього воно втратить своїх вірних бо ж постійна абсолютизація гріховності принижує людину. Харизмати, як постмодерна християнська течія, вже дещо враховують це. Вони славлять і возвеличують Ісуса за все те добре, що він зробив і робить, а не постають перед ним в ролі настирливих прохачів, не старцюють, а працюють. 
Практичне релігієзнавство відтак актуалізує не лише питання функціональності релігії, а й іiі цінності. Проблема аксіології релігії, іiі етичних норм у їхньому взаємозв'язку із соціальним станом людини важлива для нього. Актуальним для нього є й питання суб'єкта релігійної діяльності. I тут ми працюємо над тим, як підняти рівень освіченості духовенства, як донести до нього здобутки не тільки релігієзнавчої, а й всієї науки.

Як бачимо тематичне поле і проблематика сучасного практичного релігієзнавства лежить на межі багатьох дисциплін - психології, аксіології, глобалістики, праксеології, соціології та ін. Лише вихід нашого фаху в практичну сферу вивільнить його від тісї кризи, яку воно переживає.

\section{ВИСНОВКИ}

\section{АКТУАЛЬНІ ПРОБЛЕМИ УКРАЇНСЬКОГО РЕЛІГІЕЗНАВСТВА}

В нашій літературі, слідуючи за професором Д.Угриновичем, ще прийнято поділяти релігієзнавство на теоретичне та історичне. Це навіть знайшло свій вияв у назві деяких релігієзнавчих кафедр, інститутів. Дещо подібну точку зору висловили й польські релігіє знавці в книзі «Релігія в сучасному світі» за ред.. Г.Зімоня (Львів, 2007.-Част.1). Не станемо тут широко дискусувати питання правомірності такого поділу. Як на нас, філософія релігії є одним із дисциплінарних утворень релігієзнавства, так само як і історія релігії. Головна специфіка релігієзнавства (на відміну від вивчення релігійних явищ окремими науками) в тому, що воно вивчає релігію не в цілому, а як ціле, в органічній сукупності всіх іiі складових i функцій. Релігія постає для нього не як статичне, а як динамічне явище. Предметом релігієзнавства $є$ функціонуюча релігія, а це функціонування відбувається через взаємодію і взаємовпливи всіх іiі складових, і не $з$ абсолютним відмиранням чогось в ній при зміні історичних епох, бо ж релігія має передісторичний зміст.

Але те релігієзнавство, яке ми викладаємо у вузах, судячи 3 новітньої підручникової літератури, є скоріше конфесійноінформативним, ніж, власне, науковим. Одні й ті ж положення 3 приводу феномену релігії, iï структури i функцій, історії i конфесійних визначеностей, якими оперували свого часу викладачі курсу 3 наукового атеїзму, повторюються нині в курсі 3 релігієзнавства, але вже без опійних оцінок, інформативно. Структура 
курсу майже не змінилася, хіба що замість тем "Релігія і наука", "Релігія і мораль", "Релігія і мистецтво" та деяких інших з'явилося більше тем 3 історії релігії, теми про конфесійні різновиди. Здрібнилися ми тут так, що “зайшли” в релігію давньої Індії, Сгипту, Месопотамії, Греції, а сьогодення релігії і конфесій розглядаємо бігло і $з$ якимсь острахом.

Більше того, є у нас ще релігієзнавці, які з певним апломбом неперевешеності свого рівня пізнань пережовуть те, що говорили науковці минулих століть або що говорять про релігію нинішні наші колеги на Заході, і вважають, що цим розвивають релігієзнавчу науку України. Але це далеко не так. Спілкуючись із зарубіжними дослідниками релігії під час своїх неодноразових поїздок за кордон на наукові конференції, я переконався в тому, що тут ми маємо справу скоріше із створеними ними якимись новими умоглядними конструктами, новими, витвореними ними, умоглядними поняттями 3 осягнення релігійних феноменів, а не 3 власне дійсним науковим аналізом багатоманіття сучасних релігійних явищ і процесів. А це має місце тому, що реальний об'єкт нашої дослідницької уваги - жива сьогоднішня релігія і релігійність - існує по суті поза ними. Читаєш праці деяких молодих наших релігієзнавців і бачиш, як вони хизуються знанням праць різних авторів - вітчизняних і зарубіжних. Цитата йде за цитатою. Втупившись в інтернет-сайти, їх не так вже й тяжко назбирати. А де ж власна думка дослідника? То ж маємо ще часто “цитувальне релігієзнавство", реферування чужих думок під певну тему підібраних. Маємо не наукове релігієзнавство, вибудуване на безпосередньому дослідженні релігійних феноменів, а плагіатне релігієзнавство, збудоване на заочному знанні релігійних процесів $\mathrm{i}$ явищ через відтворення чогось і кимось написане щодо релігії. Біда наша в тому, що пошесть «плагіатного релігієзнавства» вразила насамперед ту наукову молодь, яка прагне прилучитися до нашого фаху. Таке «релігієзнавство» не має своєї перспективи: воно позажиттєве.

Чи часто наш сьогоднішній молодий релігієзнавець буває в храмах і молитовних будинках різних конфесій, чи читає він нині багатий видрук різноконфесійної літератури i періодики, чи регулярно він слухає радіо- i дивиться телепередачі 3 релігійної тематики, виходить на релігійні сайти, веде бесіди з богословами, релігійними діячами, просто віруючими різних конфесій? Ні й ні. Мене страшить те, що релігієзнавство розвивається як якась наука в собі. Ми часто працюємо в рамках наших професійних видруків, дискутуємо один з одним, розвиваємо чи завиваємо один одного, не 
рахуючись навіть 3 тим, що, крім академічного (світського), є ще й богословське релігієзнавство, класичним представником якого в Росії, скажімо, був Олександр Мень. Та й інші були ( і не лише в Росіi). То ж я закликаю (і ми в себе в цьому плані працюємо) до творчої співпраці академічних і богословських релігієзнавців, до здолання релігієзнавства як науки-в-собі, «заочного релігієзнавства».

Можна багато говорити i писати про здобутки українських релігієзнавців, про видрук тільки Відділенням релігієзнавства ІФ НАНУ протягом останніх 12 років більше 300 лише книг і часописів, не говорячи про сотні статей. Але вони не мають закривати очі на те, що воно має й вияви кризи, які виражаються, на мою думку, в наступному.

1. Наявне відмежування релігієзнавства як науки від релігієзнавства як навчальної дисципліни, а відтак тематична й змістовна закостенілість останнього.

2. Сформувалася певна непорушна окресленість (завершеність) тематичного поля релігієзнавства, що є навіть запозиченою в своїй структурній основі із колишнього курсу наукового атеїзму.

3. Наявна відстороненість від релігієзнавчого аналізу протистояння різних думок, різних позицій (в т. ч. й вільнодумчих) на феномен релігіі.

4. Має місце певна заангажованість дослідників і педагогів на християнстві й перенесення його особливостей як релігії на весь релігійний феномен, на всі конфесійні вияви релігійності.

5. Релігієзнавство розвивається як наука-в-собі, бо ж, замість вивчення реальних процесів релігійного життя, дослідники копирсаються в думках і судженнях своїх колег минулого часу і сьогодення. Релігієзнавство відтак постає загнаним в глухий кут ізоляції від практичної релігійної дійсності, своєрідною релігієзнавчою маніловщиною.

6. Маємо домінування в релігієзнавчих виданнях i дослідженнях висновків і описань авторів минулого (Тейлор, Фрезер, Леві-Брюлль, Мюллер, Еліаде та ін.). Користування в наукових висновках і викладанні навіть ілюстративним матеріалом з творів цих авторів минулих століть.

7. В релігієзнавчу освітню сферу прийшло багато тих, хто не має належної підготовки з фаху, а відтак вони часто лише дискредитують i знецінюють релігієзнавство як науку i навчальну дисципліну. 
8. Маємо здрібнення i дублювання тематики наукових досліджень, втечу в дослідницькій роботі від актуальних проблем сьогодення у вивчення переважно проблем і подій історії релігії, історії духовності, вивчення без знання відповідної мови релігій певних зарубіжних країн, їх функціональності там. Як можна, скажімо, писати про вплив ісламу на арабську культуру, вважати себе фахівцемісламознавцем без знання арабської мови або ж вивчати релігію Індії без знання санскриту.

9. Наявна широка компіляція і плагіат матеріалів Інтернетсайтів й подання їх як свого здобутку без будь-яких посилань. Наявний такот переклад зарубіжних релігієзнавчих видань українською мовою і видрук їх вже за своїм прізвищем як своїх наукових праць чи навчальних посібників.

10. Українське релігієзнавство має визнані здобутки в дослідженнях 3 історії, політології та етнології релігії, християнської конфесіології, проблем суспільного буття релігії. Водночас відсутні значимі наукові розробки 3 філософії і феноменології релігії, з історіософії, соціології і психології релігії. Дослідження таких релігієзнавчих дисциплін як «Економікологія релігії», «Етикологія релігії», «Релігієзнавча саєнтологія», «Культурологія релігії», «Правологія релігії (назва їх умовна) лише розпочинається, тематичне поле i понятійно-категоріальний апарат їх ще визначився. А між тим без усього цього комплексу релігієзнавчих дисциплін ми не матимемо всієї повноти релігієзнавства як гуманітарної науки, без викладання таких навчальних дисциплін на факультетах релігієзнавчої спеціалізації освіта буде неповною, половинчатою. Попервах можна лише рекомендувати включити до навчальних планів релігієзнавчих спеціалізацій курс «Дисциплінарне релігієзнавство», підручник 3 якого буде нами видрукуваний в цьому році.

Враховуючи те, що нині в Україні практично є одна академічна наукова установа 3 релігієзнавства, яка не може своїм штатом охопити всі актуальні проблеми нашої науки, прагнутимемо вирішити це питання шляхом кооперації наукової роботи всіх науковціврелігієзнавців країни. Ми передбачаємо створення при Українській Асоціації релігієзнавців тематичних дослідницьких груп iз включенням до складу кожної з них науковців з різних наукових чи 
освітніх установ України. Скажімо, будуть наукові тематичні групи з дослідження православ'я, католицизму, протестантизму, ісламу, нових релігійних течій, сучасної містики, історії християнства, історії релігії в Україні, історії релігієзнавчої і богословської думки, проблем свободи совісті тощо. Будуть групи 3 філософії релігії, психології релігії, правології релігії, етикології релігії, культурології релігії, богословського релігієзнавства та ін. Робота груп буде плануватися i виявлятиметься у виданні колективних монографій. Варто провести також спеціалізацію обласних осередків УАР в проведенні наукових конференцій, щоб усунути наявне дублювання в їх тематиці. До послуг дослідників релігії Центр релігійної інформації і свободи УАР відкрив в Києві Бібліотеку релігієзнавця, яка постійно поповнюється новинками фахової і богословської літератури. При ній працює зал релігійної та релігієзнавчої періодики.

Будемо сподіватися, що нам пощастить здолати ті труднощі, які переживає нині наша наукова сфера, хоч загалом наші здобутки все ж виглядають значно вагомішими, ніж в наших колег з ближнього зарубіжжя. Ніхто там не має трьох періодичних видань, а у нас $є$. Це "Релігійна свобода", "Українське релігієзнавство" та "Релігійна панорама". Там не проводяться, як у нас, щороку, з видруком матеріалів, десяток наукових конференцій. У них відсутня у вузах як обов'язкова навчальна дисципліна "Релігієзнавство". Вони не беруться до видруку багатотомної історії релігії своєї країни чи релігієзнавчої енциклопедії. Ми це маємо, але завжди хочеться більшого і кращого. 